\title{
Os estudos policiais nas ciências sociais: um balanço sobre a produção brasileira a partir dos anos 2000
}

\author{
Jacqueline Muniz ${ }^{1}$ \\ Haydée Caruso ${ }^{2}$ \\ Felipe Freitas ${ }^{3}$
}

\section{É assunto de polícia? É assunto de abordagem das ciências sociais}

Como a polícia se torna um tema de estudo relevante nas ciências sociais no Brasil? Como as organizaçóes policiais se converteram em um objeto relativamente autônomo de conhecimento? Esses são questionamentos de base que inquietam os autores e que, por meio do mapeamento, da sistematização e da análise do perfil da produção bibliográfica dos últimos anos, serve como fio condutor deste artigo.

Seria possível afirmar que a polícia e o que gravita em torno de suas visóes de mundo, estruturas, funçóes e práticas caracterizam-se como uma problemática obrigatória 4 a ser enfrentada pelas ciências sociais brasileiras? Mas em que contexto sócio-político e histórico os estudos sobre a polícia, os policiais e os policiamentos se iniciam? Que caminhos foram percorridos pelos cientistas sociais que se dedicam a esse campo? Que temáticas foram exploradas e se constituíram como importantes aportes para compreender as organizaçóes policiais e integrantes, seus fins, meios e modos de atuação?

Importa registrar que os estudos sobre polícia, do final dos anos 1990 para cá, ganharam em qualidade e quantidade. Hoje constituem rico sortimento tanto de alternativas diversas de temas e análise quanto do volume ampliado de distintos trabalhos desenvolvidos e publicados. Importa também ressaltar que, de algum modo, esta respeitável e vasta produção suscita, ainda, importantes questionamentos sobre suas possíveis implicaçôes nas políticas públicas de segurança pública experimentadas no Brasil.

Diante de uma produção científica em crescimento, não é exagero afirmar que os estudos sobre a polícia têm mobilizado, além do previsível ativismo jurídico e da militância dos direitos humanos, antropólogos, sociólogos e cientistas políticos, a partir de diferentes lugares de produção de conhecimento sobre o tema (ADORNO, 2001; BARREIRA; ADORNO, 2010; KANT DE LIMA; MISSE; MIRANDA, 2000; ZALUAR, 1999a, 1999b).

1 Antropóloga; professora do Departamento de Segurança Pública da Universidade Federal Fluminense (UFF). E-mail: jacquelinedeoliveira.muniz@gmail.com

2 Antropóloga; professora do Departamento de Sociologia da Universidade de Brasília (UnB). E-mail: haydee.caruso@yahoo.com.br

3 Criminólogo; doutorando em direito pela Universidade de Brasília (UnB). E-mail: fsfreitas_13@yahoo.com.br

4 Utilizamos problemática obrigatória para compreender a polícia como objeto de estudo nas ciências sociais, nos termos propostos por Bourdieu (2001) em que algumas questóes se constituem em "repertório de lugares-comuns", "não apenas um discurso e uma linguagem comuns, mas também terrenos de encontro e acordo, problemas comuns e maneiras comuns de abordar tais problemas comuns" (Ibidem, p. 207). Para o autor, pouco importa se os intelectuais discordam das questóes que discutem. O que está em jogo é estar de acordo em discuti-las. Neste ponto, tal noçáo torna-se chave para o argumento que pretendemos desenvolver, uma vez que se busca demonstrar que a polícia, enquanto objeto de estudo, consolida-se nas ciências sociais. 
Um olhar atento para o conjunto de estudos sobre as polícias, sob a perspectiva das ciências sociais, explicita os diversos trânsitos temporais e espaciais feitos por pesquisadores ${ }^{5}$, policiais, gestores públicos, ativistas de direitos humanos, entre tantos outros atores que, de modo variado, contribuíram para um campo de pesquisa em franca consolidação. A ideia de trânsitos temporais e espaciais busca incorporar a itinerância profissional realizada por aqueles atores que, em períodos e contextos distintos, voltaram seus interesses para as polícias e seus diversos mundos. E, sobretudo, reconhecer como estes fluxos entre o mundo das ONGs, do governo, da Academia e das polícias acabaram por produzir efeitos interessantes, como a própria configuração multidisciplinar e intersetorial dos estudos policiais. Afinal, os trânsitos realizados por tais pesquisadores alimentaram e retroalimentaram a produçáo acadêmica desenvolvida por eles, uma vez que o exercício de distintas atividades - acadêmicas, públicas e privadas - permitiram construir e confrontar novos ângulos de observaçáo da realidade e suscitaram nestes cientistas sociais novas questóes e enfoques para velhos problemas relacionados às polícias.

Interessados em mergulhar no universo de estudos que elege a polícia como objeto privilegiado de sua abordagem, propomos neste artigo uma dupla tarefa: revisitar os levantamentos bibliográficos já produzidos com uma lupa que permita "enxergar" e interpretar o surgimento dos estudos policiais, como também realizar um balanço do que foi produzido, entre 2000 e 2017, considerando as três grandes áreas das ciências sociais: antropologia, sociologia e ciência política.

Para cumprir o desafio proposto, optou-se por organizar o artigo em três partes. Na primeira, busca-se situar e entender o "lugar" que ocupa os estudos policiais nas ciências sociais brasileiras. Tem como pretensão demonstrar como o campo emerge e deixa de ser exclusivamente um legítimo problema social, recorrente da vida cotidiana nacional, e passa a se configurar, também, como uma legítima problemática sociológica, com seus desafios, ambiguidades e possibilidades de interpretação. Para tanto, foram revisitados os artigos anteriores que objetivaram descrever e analisar a produção bibliográfica sobre os temas da violência, criminalidade, justiça criminal e segurança pública. Revisitá-los, neste caso, significou identificar neles como e por que se deu o início da produção específica sobre as polícias e que temas foram inicialmente contemplados nesses estudos. Náo se tratou de fazer uma história dos estudos e pesquisas que abordam a polícia como recorte central, mas encontrar na leitura desses levantamentos prévios os contextos e inquietaçóes que despertaram o interesse dos cientistas sociais.

A segunda parte corresponde a uma seção de passagem redigida como uma breve nota que traz os pontos importantes sobre o levantamento realizado, incluindo as dificuldades encontradas para a realização desse exercício

5 Cabe citar alguns pesquisadores, em ordem alfabética, que exerceram importantes funções públicas, municipais, estaduais e federais, no âmbito da segurança pública, a partir do final dos anos 1990: Ana Paula Mendes de Miranda (UFF), Arthur Trindade (UnB), Cesar Barreira (UFC), Claudio Beato (UFMG), Haydée Caruso (UnB), Jacqueline de Oliveira Muniz (UFF), Jorge da Silva (UERJ), José Luiz Ratton (UFPE), Julita Lemgruber (CESEC/UCAM), Luiz Eduardo Soares (UERJ), Luís Flávio Sapori (PUC-MG), Paulo Sérgio Pinheiro (USP), Renato Sérgio de Lima (FBSP), entre outros. A chamada "ida para o governo" implicou a construção de políticas e planos de segurança pública que, por processos distintos, destacavam a importância da gestão do conhecimento e da informação aplicados à segurança como recurso indispensável à implementação de políticas públicas. Esta e outras iniciativas que valorizaram a produção de diagnósticos qualificados contribuíram para a expansão da produção acadêmica sobre as polícias e os policiamentos nas ciências sociais brasileiras. 
analítico. Nela, são apresentados os procedimentos metodológicos que orientaram a produção do corpus empírico que sustenta os resultados apresentados neste artigo.

A terceira parte apresenta um panorama geral do que foi levantado, considerando alguns marcadores identitários dos autores bem como os temas propostos por eles. Por fim, o artigo apresenta uma lista classificatória que poderá ser útil para a navegação dos futuros(as) pesquisadores(as) da área pelas fontes consultadas neste trabalho. Em síntese, estão dispostos um conjunto de subsídios extraídos dos estudos levantados que, analisados em conjunto, permitem apresentar um balanço, mesmo com algumas lacunas, da produção desenvolvida nos últimos 17 anos, no Brasil.

\section{Parte I: De problema social à problemática sociológica - a construção de um lugar para os estudos policiais nas ciências sociais}

Motivados em apresentar ao leitor as trilhas e atalhos que nos levam a entender como o tema polícia ganhou relevância para os pesquisadores brasileiros, recorreremos, brevemente, aos importantes - e ainda atuais - levantamentos produzidos por Alba Zaluar (1999a, 1999b), Kant de Lima, Michel Misse e Ana Paula Miranda (2000), Sérgio Adorno (2001), César Barreira e Sérgio Adorno (2010) e, mais recentemente, Marcelo Campos e Marcos Alvarez (2017) ${ }^{6}$. A partir dos percursos realizados por esses autores, buscou-se compreender as formas de inserção da polícia enquanto temática ${ }^{7}$. Tratou-se de apreender os modos pelos quais esse tema vai se apresentando nos estudos, cujo propósito primeiro era cobrir, de maneira mais abrangente possível, a literatura especializada sobre violência, criminalidade, justiça criminal e segurança pública.

Os caminhos metodológicos traçados pelos autores para construir seus mapeamentos bibliográficos foram diferentes entre si, porém neles identificam-se elementos comuns que lançam luzes sobre o processo de inserçáo da polícia como objeto das ciências sociais. Desses trabalhos pode-se fazer aparecer uma espécie de mito de origem da inscriçáo do tema no rol das preocupaçóes intelectuais dos cientistas sociais brasileiros.

Tem-se um lugar dos estudos policiais que desliza entre a descrição e a prescrição de realidades, a um só tempo, sob exame de um olhar investigativo e sob prova de um olhar interventor. Um lugar que se abre à urgência política das demandas sociais por "reforma das polícias", e que, por isso mesmo, se insere entre a temporalidade por resultados e soluçóes e a temporalidade da investigação. Um lugar entre pesquisa e ação, a criar uma passagem cujos sentidos seguem nessa máo dupla que pavimenta um caminho que vai e volta de um problema social para uma problemática sociológica. Um lugar que segue em processo de construção e na procura por uma identidade própria: uma ciência social da polícia que se ocupe de desenvolver teorias e metodologias considerando as especificidades da realidade policial.

6 Um levantamento inicial foi feito por Sérgio Adorno (1993), todavia, optamos por não o incluir no escopo de análise, uma vez que o autor em seu artigo "Monopólio estatal da violência na sociedade brasileira contemporânea" (2001) reconhece que o primeiro levantamento por ele elaborado havia sido superado por aqueles feitos por Zaluar e Kant de Lima, Misse e Miranda (2000). Desse modo, tomamos como referência inicial para a discussão proposta os artigos "Violência e crime" (1999b) e "Um debate disperso: violência e crime no Brasil da redemocratizaçáo" (1999a), ambos de Zaluar.

7 Ao buscar os estudos que tratam da temática "polícia” a partir dos levantamentos, considerou-se tanto os que fizeram da polícia a questáo central do trabalho quanto aqueles em que ela aparece como contraponto ao objeto principal de investigação. 
Se pensarmos numa linha do tempo, veremos que Zaluar, no final dos anos 1990, estava interessada em circunscrever o debate entre cientistas políticos, antropólogos e sociólogos que estudaram o tema "violência e criminalidade" a partir de perspectivas e abordagens distintas. A autora mostrou-se estimulada em situar o estágio em que o campo se encontrava, explorando as convergências e divergências entre os pesquisadores, isto é, as concepçóes e suas formas de enquadramento acerca dos fenômenos cobertos pelo grande paraquedas da violência e do crime. Para autora, até aquele momento, o debate ainda poderia ser considerado disperso, uma vez que este ainda náo tinha sido organizado e bem fundamentado teoricamente. Por esse motivo, a escolha analítica da pesquisadora desviou-se da pretensão de buscar modelos teóricos construídos pela área, voltando-se para mapear os temas presentes na literatura especializada (ZALUAR, 1999a). Como resultado desse empreendimento, ela apresenta a proposiçáo de cinco grandes eixos que aglutinam, a seu ver, a seleta de estudos por ela consultados:

1) a reflexão sobre o que é violência $[\ldots]$; 2) as imagens ou representaçóes sociais do crime e da violência e o medo da população [...]; 3) contar as vítimas e os crimes [...]; 4) a procura de explicaçốes para o aumento da violência e da criminalidade [...]; 5) o problema social da criminalidade como tema de política pública. (Idem, 1999a, p. 8)

As chaves de agregação temática propostas caracterizam, antes, as escolhas da própria autora, pesquisadora pioneira da área, sobre as questóes que considerava prioritárias e de maior relevo no campo dos estudos da violência e do crime, na época de realização do seu levantamento. Diante dessa constatação, buscou identificar quais seriam as preocupaçóes relevantes nos trabalhos de seus pares.

Constata-se que a palavra "polícia" ou alguma expressão que remeta às representaçóes e práticas policiais não aparece nos eixos classificatórios. É fato que a polícia existia nas realidades da violência e do crime, porém, esta não deu o ar de sua existência como uma das categorias de indexação elaboradas por Zaluar. É significativo que o mundo da polícia ainda não fizesse parte da linguagem acadêmica autorizada, ainda que fosse autor de um tipo de violência, a chamada "violência estatal". Nem bem, nem mal dita, a temática da polícia seguia não dita, uma realidade interdita que ainda não estava explicitamente anunciada pelos enunciados classificatórios. Mas o que essa invisibilidade da temática da polícia pode comunicar?

De fato, a polícia não figurava como temática importante para os pesquisadores pioneiros da violência. As polícias e suas práticas ocupavam um lugar secundário nas reflexões, salvo exceções, como os trabalhos inaugurais de Paixão (1982, 1995), Kant de Lima (1995, 1997) e Oliveira (1985a, 1985b, 1985c). As apariçóes desses temas nos artigos acadêmicos tendiam a ser indiretas, como algo já sabido a ser imputado como agente (re)produtor de violaçóes do que como algo a ser investigado e compreendido por dentro. Parecia suficiente para compreensão da violência e do crime tratar a polícia como uma abstração genérica, cuja explicação estava fora dela, em outro ente, também abstrato e desencarnado, chamado Estado (MUNIZ, 1999). Na periferia dos interesses acadêmicos, a polícia surgia subalterna, tal como seus integrantes vindos das classes populares, um corpo sem alma e sem projetos próprios de poder.

Reduzida a uma instrumentalidade, a polícia não aparecia como algo em si mesmo, uma realidade complexa e singular a ser desvendada. Não havia muito o que conhecer na polícia. Bastavam a sua caracterização como "aparelho repressivo do Estado”, a apuração e a denúncia dos efeitos perversos de sua ação. Portanto, os olhares de fora, de cima e ao redor da polícia. 
Dessa forma, mantinha-se uma boa distância com quem controla, disciplina e corrige, enfim com quem regula pela distribuição seletiva de coercitividades (MUNIZ, 1999). Assim, manobrava-se com as restriçóes institucionais o trabalho de pesquisa independente no interior das polícias. Olhares de dentro costumavam esbarrar nas alegaçóes dos comandos e das autoridades governamentais quando acionavam, sempre que oportuno, a "razão de estado" ou a "razão de segurança” para manter as polícias o mais distante possível do mundo da pesquisa. Portanto, parecia mais apropriado que a polícia que investiga para prender nâo fosse ela própria investigada para ser apreendida como objeto da compreensão crítica.

Já Kant de Lima, Misse e Miranda (2000) identificaram ser possível "propor uma abordagem sistemática” da bibliografia da área. E, para isso, consideraram que as (até então) duas décadas de acúmulo regular de interpretaçóes e materiais empíricos, bem como a presença dos intelectuais da área no espaço público, debatendo questóes relativas à segurança pública e justiça criminal, traduziam-se em critérios incontestes de que já seria possível desenvolver uma análise comparada dessa produção (Ibidem, p. 45). Chama atenção que, segundo a sistematização dos dados levantados pelos autores, quase dois terços dos pesquisadores registrados nos Diretórios de Grupos de Pesquisa do Conselho Nacional de Desenvolvimento Científico e Tecnológico (CNPq) e associados ao "setor de atividade" denominado "segurança pública e criminalidade" concentravam-se na área de humanidades e, ainda, que 60\% das linhas estavam vinculadas às ciências sociais (Ibidem, p. 45). Essa expressiva concentração não chega a ser surpreendente, se consideramos que a violência e o crime e, por sua vez, o controle social, o conflito, a coerção e o desvio constituem um repertório temático clássico das ciências sociais desde a sua constituição. Ademais, a despeito das possíveis ondas de modismo temático, tais assuntos seguiram mobilizando o interesse de pesquisadores de diferentes geraçóes e em distintos momentos de suas trajetórias acadêmicas. Parece servir de contexto sociopolítico para esse interesse expressivo na problemática da segurança e do crime, o comportamento crescente das taxas de criminalidade violenta no $\mathrm{Brasi}^{8}$, nas décadas de 1980 e 1990, e também o ingresso na agenda pública das demandas por reforma das agências estatais de controle e regulação como parte indispensável do processo de redemocratização do país e de avanço da cidadania.

Kant de Lima, Misse e Miranda (2000), assim como Zaluar, apresentam ao leitor uma proposta classificatória para o acervo que conseguiram levantar entre 1970 e 2000 . Interessa aqui chamar atenção para a categorização que propuseram, uma vez que essa proposta classificatória é também reveladora das inscrições da polícia, como tema de pesquisa, na narrativa das ciências sociais. Neste caso, apresentaram as seguintes temáticas, incluindo subdivisóes para a primeira: (1) A temática da delinquência e da criminalidade violenta subdividida em (a) delinquência infanto-juvenil e a categoria de "menor"; (b) aumento da criminalidade urbana, mudanças de padrão e perfil social dos acusados e seus efeitos de violência; (c) a questão do crime organizado e do tráfico de drogas; (2) a temática da polícia e do sistema de justiça criminal; (3) a temática das políticas públicas de segurança; (4) a temática da violência urbana (imagens, práticas e discursos).

8 O Anuário Brasileiro de Segurança Pública, organizado pelo Fórum Brasileiro de Segurança Pública, organização não governamental, é a principal fonte de dados consolidados sobre criminalidade, sistema prisional e segurança pública, em âmbito nacional. Conferir: <http://www.forumseguranca.org.br/atividades/anuario/>. 
Note-se que a estrutura classificatória concebida pelos autores conjuga o que seriam os problemas sociais, suas expectativas de resolução e a problemática científica que os conforma. Tem-se, com esse modo de categorizar a produção científica mapeada, um esforço de conferir visibilidade acadêmica a instituiçóes, sujeitos, discursos e práticas. É nesse tipo de enquadramento, que incorporou um universo maior de referências e com um recorte temporal mais amplo, que a polícia é protagonizada como objeto de estudo em duas temáticas, podendo ainda se fazer presente, de forma indireta, nas demais temáticas concebidas. Parece-nos que há um fio condutor implícito, o binômio sociedade e estado, que se desdobra nas relaçóes de poder, seus regimes de verdade e suas formas de administração de conflitos. Ampliou-se a chave indexadora pela inclusão da expressão "segurança pública" - uma categoria de origem política, cuja definição e alcance, sua descrição e prescrição seguem em disputa entre operadores, ativistas e pesquisadores (COSTA; LIMA, 2014; MUNIZ, 2012a).

Na sequência, em 2001, Adorno 9 publica um ensaio onde realiza uma abordagem diferenciada da questáo, mas igualmente interessante para a compreensáo do campo. $\mathrm{O}$ texto não se configura necessariamente em mais um levantamento, tal como os anteriormente produzidos, mas investe em referências de maior impacto no campo, considerando aquelas produzidas pelos scholars da área, em particular do campo tradicional da violência urbana que, anterior às terminologias mais recentes como "segurança pública", "estudos policiais", abrigava os pesquisadores seniores.

Como o interesse desse autor não era produzir uma lista exaustiva destes scholars, ele procurou dialogar com aqueles que poderiam ser compreendidos como influenciadores do debate; e que, de alguma forma, seriam vistos como precursores da construção de uma agenda política, tanto em círculos acadêmicos como nâo acadêmicos e, igualmente, envolvidos na formação de novos pesquisadores do campo. Nesse caso, um autor e uma de suas obras em particular ganhou destaque na análise empreendida por Adorno. Trata-se da autoetnografia ${ }^{10}$ Meu casaco de general, escrita por Luiz Eduardo Soares (2000a), em que retrata, a partir de sua experiência, os 500 dias que esteve à frente da política de segurança pública do estado do Rio de Janeiro, durante o governo de Anthony Garotinho (1998-2002) ${ }^{11}$.

É a partir dos insights teóricos subjacentes na narrativa pessoal e etnográfica do autor que Adorno percorreu aquilo que identifica como

um dos objetos mais caros à sociologia política: o monopólio estatal da violência física legítima, em torno do qual gravitam outros temas como: 1) soberania política e o futuro do Estado-Nação; 2) lei e ordem versus direitos humanos; 3) legitimidade, autoridade e justiça pública. (ADORNO, 2001, p. 171)

Ressalte-se que, uma vez mais, a problemática dos estudos policiais é contemplada

9 O artigo integra o volume IV da coletânea O que ler na ciência social brasileira (1970-2002), publicado pela Anpocs. Conferir: <http://www.anpocs.com/index.php/universo/acervo/biblioteca/coletaneas/o-que-ler-na-ciencia-social -brasileira-1970-2002/volume-iv/663-monopolio-estatal-da-violencia-na-sociedade-brasileira-contemporanea>.

10 Nesse caso, o termo autoetnografia está em uso aqui na medida em que Adorno chama atençáo para o fato de que a narrativa empregada pelo pesquisador e/ou gestor Luís Eduardo Soares articula sua visão pessoal sobre o vivido entremeada por análises etnográficas em que o vivido foi compreendido como drama social, nos termos propostos por Victor Turner (2013).

11 Entre março e dezembro de 2002, Anthony Garotinho licenciou-se do Governo do Estado para candidatar-se à Presidência da República, assumindo a vice-governadora Benedita da Silva (PT). 
de forma indireta, porém atravessa implicitamente os três grandes eixos de agregação propostos. Não se tem um nome, mas descritores dos lugares conceituais de polícia conforme aparece explicitamente na produção internacional: Polícia como meio de produção de alternativas de obediência às regras do jogo, com o recurso potencial e concreto de força, sob consentimento social (MUNIZ, 1999); Polícia como expressão de soberanias sob populaçáo e territórios; Polícia como dispositivo de administração de conflitos, de negociaçấo das interpretaçóes da lei e das expectativas de ordem (MUNIZ; PROENÇA JÚNIOR, 2014a).

As temáticas sugeridas objetivaram colocar a literatura brasileira em diálogo com as tradiçóes da literatura estrangeira, principalmente europeia e norte-americana que tratam da relação entre Violência e democracia. Interessante observar que Adorno, ao contrastar a produção brasileira e internacional, visava pôr em relevo uma das inquietaçóes mais pujantes para os pesquisadores $\mathrm{da}$ área e que se traduz no binômio violência versus direitos humanos.

Pode-se dizer que se trata - ainda - de um dos pontos de partida que os pesquisadores da área estáo interessados em adotar. Vale aqui considerar esse ponto como uma das janelas de análise que é recorrentemente acionada, mas que, por vezes, recai sobre explicaçôes tautológicas do fenômeno em que o conhecimento produzido sobre as polícias já parte de um lugar predeterminado, e porque não dizer pendular, no qual as polícias, ora são produtoras de violência institucional, ora garantidoras de direitos humanos.

Passados dez anos, César Barreira e Sergio Adorno (2010) investem na atualizaçáo dos levantamentos bibliográficos supracitados e, dessa vez, propóem cobrir, de modo preferencial, o campo especializado da sociologia. Com destaque para um campo diverso e controverso denominado sociologia da violência que, para os autores, mantém conexôes óbvias com as ciências sociais como um todo, mas que podem ser mapeadas a partir do que produziram os pesquisadores vinculados à sociologia ou em diálogo com a área.

O que importa assinalar é que também nesse levantamento, os autores reforçam a compreensáo do campo a partir do repertório temático que dele emerge. Salientam que as temáticas trabalhadas por Zaluar (1999a, 1999b) e Kant de Lima, Misse e Miranda (2000) continuam atuais e aplicáveis ao campo específico da sociologia. E, como tentativa de compreensão do estado da arte da sociologia da violência no Brasil, apresentam aquilo que denominaram tendências na agenda de investigação. As tendências permitem captar os contextos, interesses e motivaçóes que ajudam a situar a produção sociológica em questão em um tempo-espaço determinado. Assim, o exercício proposto pelos autores reforça uma linha argumentativa, de certo modo consensual na área, de que o controle da violência continua como um dos graves desafios às políticas governamentais. (BARREIRA; ADORNO, 2010). Portanto, é a partir dessa questáo central que os autores constroem uma narrativa sobre a construção do campo.

O levantamento mais recente da área foi produzido por Campos e Alvarez (2017) e teve como foco, assim como os demais aqui citados, analisar a produção científica no âmbito dos estudos da violência no Brasil, considerando um período mais recente que compreendeu de 2000 a 2016. E, como tem sido retratado nas revisóes anteriores, os autores também seguiram o caminho de apresentar as temáticas que mobilizaram os pesquisadores da área e não as linhas teóricas e rumos metodológicos. A recorrência da adoção desse tipo de estratégia permite supor que o elemento de vinculaçáo dos pesquisadores é sua escolha temática e suas questóes, muito mais do que as filiações 
teóricas e/ou abordagens metodológicas adotadas. Isso evidencia um ecletismo que favorece as individualidades, mas também póe em cena uma configuração tão multifacetada que desafia a construção de um consenso mínimo sobre o estado da arte do campo.

Campos e Alvarez (2017) apontam para a possível consolidação da temática das "políticas públicas de segurança”, considerando a repercussão que esse grande tema teve nas publicaçóes referenciais na área de sociologia. Essa temática diversifica-se internamente, a partir de distintos rótulos que os autores exploraram para tentar dar conta dos enfoques propostos pelos pesquisadores. Como exemplo, pesquisas sobre "fluxo", "justiça criminal", "administração institucional de conflitos"; "reforma da justiça", "polícia”; "segurança privada", "segurança pública", "determinantes da criminalidade", "prevenção ao crime e política criminal", "estatísticas criminais", "oportunidades do crime" e "violência de gênero" (CAMPOS; ALVAREZ, 2017, p. 145). ${ }^{12}$

Constata-se em todas as revisões aqui brevemente apresentadas uma urgência em compreender como o campo se organiza, mesmo com suas idiossincrasias, ambiguidades, interconexôes e diversidades internas. Observa-se, também, que as alterações das grandes chaves indexadoras refletem mudanças de prioridades e alteraçôes de ênfases. Mas, sobretudo, revelam disputas geracionais entre a sociologia, a ciência política e a antropologia. As escolhas de tal ou qual chave de indexação são antes políticas e apontam para o perde $\mathrm{e}$ ganha de prestígio e influência, para o que se torna nomeável e visível. Nessas últimas três décadas, a classificação inicia-se com os direitos humanos, desloca-se para a violência e crime, chegando à segurança pública e justiça. Quanto mais se caminha para a defesa da grande chave "segurança pública", mais são incorporados os pesquisadores das novas geraçôes e seus temas emergentes, o qual incluem as polícias. Cabe ressaltar que a chave "segurança pública" configura-se, no tempo presente, como o lugar por excelência de embates entre sociedade, Estado e academia. Isso corresponde a uma arena de confrontos entre ativistas, operadores, gestores e pesquisadores.

Das descrições e análises empreendidas, conseguimos apreender alguns blocos de sentido que podemos organizar em três grandes eixos temáticos que organizam - de certo modo - a agenda de pesquisa, especificamente sobre a polícia nas ciências sociais. $\mathrm{O}$ primeiro seria "violência e crime", em seguida "polícia e ordem pública" e o terceiro "políticas públicas de segurança e justiça”"13.

Quanto ao primeiro bloco "violência e crime", as revisôes de literatura o apontam como uma espécie de eixo iniciático do tema no Brasil, ao mesmo tempo que permanece como o principal guarda-chuva que continua a abrigar a produção acadêmica ${ }^{14}$. Nesse bloco, os estudos sobre a polícia surgem, como diria Zaluar (1999a, p. 9), da urgência em se discutir "a violência advinda do poder ilegítimo do Estado" e, como tal, ganhou espaço e permaneceu na agenda dos cientistas sociais, desde o período da ditadura civil-militar até os dias atuais. Todavia, é no contexto de

12 Por se tratar de rótulos associados aos artigos de autores da área e que foram cuidadosamente analisados por Campos e Alvarez (2017), vale conferir as referências bibliográficas elencadas no referido estudo, uma vez que, por limitação de espaço, não seria possível aqui reproduzir.

13 Os nomes desses blocos aproximam-se das formas como as agências estatais brasileiras, principais demandantes de pesquisas aplicadas na área, em especial aquelas do Poder Executivo, reconhecem como os grandes eixos do campo.

14 Pode-se dizer que isso resulta da tradiçâo desta primeira temática. Também evidentemente é resultado de prestígio e influência política dos seus representantes nos órgãos públicos de fomento e na máquina estatal. 
redemocratização do país, ao final dos anos 1980 e início dos anos 1990, que os estudos sobre "violência policial", "corrupção policial" e "grupos de extermínio" ganham espaço entre os cientistas sociais.

Kant de Lima, Misse e Miranda (2000) afirmam que as transformaçóes jurídicas e políticas vividas pelo país, nesse período, permitiram - de alguma maneira - um maior trânsito dos pesquisadores nas instituições judiciais e policiais. É por isso que "começa a desenvolver-se, a partir da década de 1980 uma sociologia da organizaçáo policial contemporânea"15.

Pode-se afirmar que, é ao longo dos anos 1990, a polícia passa efetivamente a ganhar lugar como problemática sociológica

seja do ponto de vista dos estudos sobre suas práticas, seja do ponto de vista das violaçôes de direitos humanos que elas produzem, seja através das políticas públicas que elas encarnam, seja a partir de suas relaçōes com diferentes segmentos da sociedade brasileira. (KANT DE LIMA; MISSE; MIRANDA, 2000, p. 52, grifo nosso). ${ }^{16}$

Diante dos interesses elencados, os anos 2000 surgem como um espaço possível de avanço dos estudos sobre a polícia e, desse modo, ela enquanto problema e tema surge com mais ênfase na narrativa acadêmica. Por essa razão, o segundo bloco, "polícia e ordem pública”, evoca um conjunto de estudos dos mais diversos e dispersos possíveis que vão desde o controle da ordem pública; a reforma das polícias; o estudo dos mecanismos de controle externo e interno; a análise do policiamento comunitário; ouvidorias, corregedorias, conselhos de segurança pública entre outros; a polícia judiciária e seus fluxos de investigação; as guardas municipais; até a participação da sociedade civil na segurança pública através de projetos específicos. Obviamente essa lista náo se esgota e nem dá conta do que foi produzido sobre as polícias. Todavia é revelador de uma inquietação acadêmica, que foi ganhando espaço e que é trabalhada pioneiramente na etnografia realizada por Muniz (1999) acerca do fazer ostensivo da polícia, que a permitiu colocar luz sobre questôes centrais envolvendo a compreensão de que o fazer policial cotidiano é a expressão pragmática, funcional, utilitária e invasiva de como sustentar o exercício de certos tipos de poder e de autoridade, às regras do jogo democrático (MUNIZ; PAES MACHADO, 2010). Compreender a polícia nos seus próprios termos permite, então, se perguntar sociologicamente: Qual Estado? Qual Ordem? E qual polícia? estamos analisando (MUNIZ, 1999).

Por fim, o terceiro bloco, "políticas públicas de segurança e justiça", remete a mais um variado universo de estudos que, obviamente, se conecta com os trabalhos sobre "polícia e ordem pública", mas que aqui são tratados separadamente. Há boas razóes para isso. Esses estudos parecem indicar, em seus esforços de análise, uma preocupação considerada por muitos dos cientistas sociais da área: uma tentativa de trazer o futuro no presente, descrevendo a realidade estudada diante da vontade de mudança que a prescrição encerra. Por um lado, denunciar as mazelas do Estado, em especial aquelas expressas nas políticas públicas de segurança e justiça. Por outro, apontar caminhos para a melhoria do "sistema", seja por sua "reforma" e/ou "modernização".

15 Sob esse ponto, conferir referências contidas na análise de Kant de Lima, Misse e Miranda (2000, p. 52).

16 Vale consultar a lista de referências bibliográficas disponíveis no artigo de Kant de Lima, Misse e Miranda (2000) e que tratam particularmente do surgimento das polícias como questão sociológica, a partir de diferentes enfoques. Conferir: <http:/www.anpocs.com/index.php/universo/acervo/biblioteca/periodicos/bib/ bib-50/514-violencia-criminalidade-seguranca-publica-e-justica-criminal-no-brasil-uma-bibliografia/file> . 
Para além do risco de sermos simplistas nessa classificação dos intelectuais em dois polos ${ }^{17}, \mathrm{o}$ que nos interessa chamar atenção é para o fato de que nesse bloco de sentido localizamos um conjunto heteróclito de pesquisas, uma espécie de exílio categorial, suficientemente elástico para caber tudo sob a latitude conceitual da categoria "políticas públicas". Identifica-se estudos engajados em apresentar cenários que levem a melhorias possíveis, por exemplo, para políticas de segurança e justiça voltadas aos públicos prioritários: mulheres, crianças, adolescentes, jovens adultos, jovens negros, LGBTs entre outros; passando por estudos sobre uso da força; fluxo de investigação policial; até aqueles voltados para as condiçôes do trabalho policial; a saúde desses profissionais; sua participação em movimento sindicais, ativismos etc. ${ }^{18}$

\section{Parte II: Breves notas metodológicas}

Torna-se, antes, necessário explicitar os critérios adotados no mapeamento realizado e que sustenta a segunda parte do $\operatorname{artigo~}^{19}$. Primeiro, optamos por trabalhar com revistas nacionais que, no quadriênio 2013-2016 ${ }^{20}$, tivessem sido avaliadas como A1, A2, B1, B2 em antropologia, sociologia e ciência política ${ }^{21}$. A exceção a esse recorte correspondeu a inclusão de artigos internacionais que tiveram alguma repercussão na literatura nacional.

No universo de revistas ${ }^{22}$ selecionadas, procedemos consultas utilizando as seguintes palavras-chave: "polícia", "policial", "policiamento", "força pública", "monopólio da violência", "segurança pública" e, neste item, em particular, realizamos novo filtro tentando

17 Isso não significa dizer que intelectuais mais críticos em seus trabalhos também não contribuam, por exemplo, com proposiçôes para as políticas públicas quando são chamados/convidados a serem ouvidos. Como afirmamos na introdução deste artigo, são vários os trânsitos entre academia e governo que marcam a configuração identitária dos/as pesquisadores do campo.

18 Barreira e Adorno (2010), assim como Campos e Alvarez (2017), chamam atençáo para o importante crescimento dos estudos sobre a puniçâa e as prisóes com ênfase para os estudos sobre os tribunais de justiça; os juizados especiais criminais; o encarceramento em massa; a ascensão e ampliaçăo de facçóes criminosas.

19 Por uma limitação de espaço, não foi possível listar todos os trabalhos levantados ao final deste artigo. Todavia, foi possível captar informaçōes relevantes que permitissem apresentar ao leitor um quadro temático que, de alguma maneira, pudesse indicar as principais tendências do campo, a partir dos objetos que foram privilegiados pelos(as) distintos(as) autores(as) brasileiros(as) consultados(as).

20 Ao escolher o quadriênio mais recente de avaliaçáo, algumas revistas que não são mais avaliadas pela Capes foram retiradas da amostra, tais como Discursos Sediciosos e São Paulo em Perspectiva que no passado recente publicaram artigos importantes para área.

21 Há que se considerar que uma mesma revista pode ter distintas avaliaçôes nas três áreas de concentração das ciências sociais ou mesmo revistas que são avaliadas por uma área e que sequer é analisada pela outra.

22 Civitas; Sociologias; Caderno CRH; Sociedade e Estado; Revista Brasileira de Segurança Pública; São Paulo em Perspectiva; Estudos Avançados; Revista Brasileira de Estudos em Segurança Pública; Cadernos Adenauer; Ciência e Saúde Coletiva; Psicologia: Ciência e Profissão; Revista Brasileira de Ciências Criminais; Boletim Segurança e Cidadania; Dados; Sequência; Dilemas; Topoi; Revista de Administração Pública; Organização e Sociedade; Espacio Abierto; Revista Administração Contemporânea; Antropolitica; Revista de Antropologia USP; Psicologia e Sociedade; Psicologia, Ciência e Profissão; Segurança e Cidadania; Aurora; Ultima Ratio; Horizontes das Ciências Sociais; Bahia Análise \& Dados; Etnográfica; Cadernos de Segurança Pública; O público e o privado; Revista Sociologia e Politica; Sociologia e Antropologia; Afro-Ásia; Sociologia Politica; Revista Brasileira de Ciência Política; Latitude; Opiniäo Pública; Tempo; Mana; Revista de Estudos em Segurança Pública; Boletim CEDES; Revista Brasileira de Sociologia do Direito; Cadernos de Ciências Sociais; Revista Brasileira de Ciências Sociais; Estudos Históricos; Horizontes Antropológicos; Cadernos do CEAS; Politéia; Revista Direito e Práxis; Almanack; Revista Brasileira Ciências Sociais; Revista de Ciências Sociais; Gestão Produção; Vibrant; Revista da Defensoria Pública do Rio Grande do Sul. 
buscar aqueles artigos que fizessem interface direta com as questôes policiais.

Todavia, pelas razões que já elencamos desde a introdução deste artigo, a temática policial requer de nós, pesquisadores(as), aproximaçóes com outros universos de produção de conhecimento, como as ONGs, governos e organismos internacionais que, indubitavelmente, potencializaram o repertório de questôes sobre a temática. Por esse motivo, também investimos em mapear as publicaçôes do período (2000-2017) que tratassem diretamente sobre o tema e/ou que foram reiteradamente citadas nos artigos levantados na primeira fase da pesquisa. Logo, foram incluídos livros, relatórios de pesquisas aplicadas, artigos, notas técnicas, informes, manuais e cartilhas ${ }^{23}$ produzidos e/ ou financiados por tais atores.

Como forma de organizaçáo do material levantado, propusemos um sistema de classificação para os documentos que permitissem produzir as análises disponíveis no tópico seguinte. Nossa classificação foi composta pelas seguintes categorias: (1) tipo de publicação $0^{24}$; (2) ano de publicação; (3) autores(as); (4) referência; (5) tipo de texto ${ }^{25}$; (6) gênero da publicação ${ }^{26} ;(7)$ identidade dos(as) autores(as ${ }^{27}$; (8) sobre o que escreve; (9) avaliação da revista de acordo com o Qualis Periódicos; (10) UF da publicação; (11) abrangência do estudo ${ }^{28}$; e (12) financiador ${ }^{29}$.

É importante situar três observaçôes quanto às limitações encontradas e às ausências de informaçóes. A primeira diz respeito aos marcadores identitários dos/as autores/as. Entendíamos como relevante levantar e sistematizar informaçóes que permitissem caracterizar a identidade socioprofissional do(a)s autores(as) como um recurso de contextualização e endereçamento, por exemplo, a idade e a raça/etnia. No entanto, essas informaçóes não estavam disponíveis. Entende-se que, no futuro, poderá ser importante compreender a diversidade (ou não) dos atores do campo.

A segunda observação refere-se a "quem assina" os documentos. Encontramos

23 Como exemplo, estudos publicados na Coleção de estudos preparatórios da Conferência Nacional de Segurança Pública (Conseg) produzida pela Secretaria Nacional de Segurança Pública do Ministério da Justiça (Senasp/MJ), ou nos sites de ONGs importantes para área como: Fórum Brasileiro de Segurança Pública, Instituto Sou da Paz, Iser, Viva Rio entre outros.

24 Os critérios foram: artigo, livro, capítulo de livro, artigo de opiniāo, monografia, dissertação de mestrado, tese de doutorado, relatório de pesquisa, nota técnica, resenha, cartilha, informe, manual e entrevista.

25 Definimos duas categorias para esse item: (a) acadêmico, ou (b) institucional (produzido por organizaçóes não acadêmicas, por exemplo);

26 Os textos acadêmicos foram classificados em: coletivos e individuais, e os textos institucionais em: governamentais e nấo governamentais.

27 Quanto à identidade dos(as) autores(as), nosso interesse foi compreender as inter-relaçóes entre pesquisadores e policiais que foram ou são pesquisadores. Há um conjunto de textos produzidos por policiais que estão na academia ou mesmo em organizaçóes governamentais e não governamentais, o que viabilizou, inclusive, a escrita de trabalhos feitos por policiais e náo policiais. Utilizamos como filtro para esse item se era um documento feito por: (a) policial; (b) não policial ou (c) misto (ambos).

28 Quanto à categoria "abrangência do estudo" interessou-nos observar se eram: (a) nacional; (b) estadual; (c) local e (d) internacional. Para aqueles que não se enquadravam em nenhuma dessas possibilidades, adotamos "não se aplica”, como exemplo, estâo assim classificados aqueles artigos que fizeram levantamentos da produçáo bibliográfica da área.

29 A categoria "financiador" permitiu observar se os trabalhos eram financiados pelo Governo Federal, especialmente Ministério da Justiça/Secretaria Nacional de Segurança Pública; organismos internacionais; agências de fomento nacionais, entre outros. Na grande maioria dos trabalhos, esse tipo de informação não se encontra disponível. 
documentos que são assinados institucionalmente como o de governos, ONGs ou organismos internacionais, mas que disponibilizaram o nome do(a) pesquisador(a) responsável. Nesse caso, optamos por manter o nome do(a) pesquisador(a) como autor(a), mas é interessante problematizar esse "duplo caráter", isto é, textos que são, ao mesmo tempo, autorais de estudiosos(as) da área e textos que produzidos, sob demanda, tornam-se também de propriedade autoral de instituiçôes públicas e/ou privadas.

A terceira observação sinaliza para o grande desafio em classificar a produçáo da área, a partir de categorias que tentem dar conta sobre o que se escreve. Essa não foi e não é uma missão trivial, pois o rol de temas, questôes, problemas, perspectivas são as mais diversas possíveis. Assim como os demais colegas que se debruçaram sobre a produção de estudos acerca da violência, criminalidade e segurança pública no Brasil, nós também encontramos uma ampla diversidade de temáticas exploradas, e nesse universo heterogêneo e pantanoso, tentamos organizar o material, a partir de categorias que respeitassem o objeto principal apresentado pelos(as) autores(as). Todavia uma ressalva precisa ser feita. Em muitos casos, assuntos aparentemente distintos reportam-se a uma mesma temática. Em outros, os temas se sobrepóem. Por isso, optamos pela dimensão que nos pareceu mais preponderante no trabalho analisado. Isso para dizer que adotamos, inicialmente, uma perspectiva indutiva de análise. Listamos todos os temas que apareciam de modo a constituir uma categorização propositalmente aberta e redundante. Depois, reorganizamos essa lista, criando novas categorias que aglutinassem ideias semelhantes que serão, de algum modo, exploradas a seguir.

\section{Parte III: Os estudos policiais produzidos entre 2000 e 2017 - números, autores(as) e temáticas}

Do tipo de publicação que recolhemos, os artigos acadêmicos compóem a principal parcela do universo analisado neste estudo. Das 400 publicaçóes levantadas, 194 são artigos publicados em revistas indexadas ${ }^{30}$ nas ciências sociais, correspondendo assim a $48,5 \%$ do universo de análise. As revistas destacaram-se como fundamentais para a ampliação do debate sobre os estudos policiais nessa área, e representam, ainda, o mais importante veículo para difusão das teses e dissertaçôes defendidas e, em alguma medida, da principal estratégia de circulação de análises realizadas por organizaçôes e movimentos sociais.

Além dos artigos, também integram o nosso escopo: livros; relatórios de pesquisa; capítulos de livro; monografias; dissertações e teses; entrevistas, cartilhas, manuais, informes, notas técnicas e artigos de opiniáo, conforme já ponderado nas notas metodológicas. $\mathrm{O}$ total de referências nesse bloco foram 206, com destaque para livros ( 56 registros), relatórios de pesquisa (46), capítulos de livros (33) e dissertaçôes e teses (46). Os demais 25 registros corresponderam então às cartilhas, manuais, notas técnicas entre outros.

As revistas que deram maior destaque à questáo dos estudos policias foram: Sociologias e Sociedade e Estado, nas quais localizamos 30 dos 194 artigos consultados. Com destaque também foram as contribuiçóes da $\mathrm{CRH}$, Civitas e Revista Brasileira de Segurança Pública que, no período analisado, editaram os dossiês Polícia e Policiamento, coordenado por Jacqueline Muniz e Eduardo Paes Machado (2010); Ensaios da mudança em polícias

30 Revistas, preferencialmente, avaliadas no quadriênio 2013-2016 como A1, A2, B1, B2, tal como já explicitamos nas Notas Metodológicas. 
de países lusófonos, editada por Cristina Zackseski (2016), e Segurança pública e reforma das polícias na América Latina, organizado por Máximo Sozzo e Rodrigo Azevedo (2016).

Alguns livros e coleções, ao longo do período, se destacaram. Primeiro, a série Polícia e Sociedade ${ }^{31}$ organizada pelo Núcleo de Estudos da Violência da Universidade de São Paulo (NEV/USP) que, com apoio da Fundação Ford e de especialistas nacionais e internacionais, disponibilizaram ao público brasileiro obras internacionais de referências sobre os estudos policiais. A série contribuiu decisivamente para o acesso de pesquisadores e policiais brasileiros a contribuiçôes sobre sistemas policiais, padróes de policiamento, inovaçóes nas polícias, administração do trabalho policial, sociologia da polícia, política da polícia entre outros temas.

Em 2007, Haydée Caruso, Jacqueline Muniz e Antonio Carballo Blanco organizaram a coletânea Polícia, Estado e Sociedade: práticas e saberes latino-americanos. $\mathrm{O}$ trabalho visou apresentar um conjunto de artigos acadêmicos e relatos policiais elaborados por mais de cinquenta autores oriundos de dez países da América Latina. Ambicionava possibilitar o intercâmbio de saberes e fazeres produzidos, de forma a contribuir para a construção de um espaço de interlocução, de produção e de divulgação de trabalhos entre policiais, ativistas e pesquisadores. $\mathrm{O}$ livro pretendeu apresentar - simultaneamente - acúmulos de pesquisa acadêmica com conhecimentos e vivências de policiais, a partir de questóes relacionadas ao mandato policial; reforma policial; responsabilizaçâo e accountability policiais, gestáo, planejamento $e$ avalição do trabalho policial; participação e controle social e polícia e juventudes.

Em 2011, Renato Sérgio de Lima, José Luiz Ratton e Rodrigo Ghiringhelli de Azevedo organizaram o livro As ciências sociais e os pioneiros nos estudos sobre crime, violência e Direitos Humanos no Brasil que reúne, no formato de entrevistas, as trajetórias dos principais pesquisadores e pesquisadoras do campo. Nessa obra fazem a reconstrução narrativa das trajetórias intelectuais, os desafios e as posiçóes colocadas diante dos lugares, nem sempre consensuais, de conciliar pesquisa e intervenção. Em 2014, esses autores também organizaram o primeiro handbook sobre Crime, polícia e justiça no Brasil que apresentou sessenta temáticas exploradas por pesquisadores das mais variadas áreas. Nessa coletânea, que se abre à inclusão dos trabalhos das novas geraçóes, tem-se, uma vez mais, um navegar por descriçóes substantivas do que seriam as principais questóes dos estudos policiais articuladas ao que seria uma agenda democrática para a justiça criminal e a segurança pública.

Em 2015, Renato Sérgio de Lima organizou a obra Narrativas em disputa: segurança pública, polícia e violência no Brasil, que traz as preocupaçóes dos seus autores, na maioria vinculados ao FBSP. Trata-se de um livro voltado para o grande público, composto por textos curtos, de fácil leitura, e que propóe apresentar uma nova narrativa das temáticas relacionadas à redução da violência no país, entre elas a policial. O projeto político do livro é claro. Faz-se uso de artigos de opinião que combinam fundamentação acadêmica e provocação argumentativa, como um modo de influenciar o debate público

31 Esta série foi editada entre 2000 e 2005. A seleção de títulos internacionais contemplados para publicação contou com as recomendaçóes de Jacqueline Muniz (UFF) que elaborou em 1998, sob demanda da Fundação Ford, e em colaboração com os pesquisadores Domício Proença Júnior (UFRJ) e Eugênio Diniz (PUC-Minas) o relatório de divulgação restrita, Ordem pública e Polícia Militar: direçóes para a Fundação Ford no Brasil, que tinha por objetivo subsidiar a tomada de decisão da cientista política Elizabeth Leeds, então gestora da Fundação Ford no Brasil, sobre suas linhas de financiamento relacionadas aos estudos policiais. Elizabeth Leeds foi a idealizadora do Fórum Brasileiro de Segurança, sendo presidente de honra até hoje. 
pelo confronto reflexivo, trazendo, mais uma vez, as constataçóes descritivas e recomendaçóes prescritivas. Também nesse ano, Renato Sergio Lima e Samira Bueno organizaram Polícia e democracia: 30 anos de estranhamento e esperança que, a partir de um sobrevoo sócio-histórico, analisam os avanços e recuos das políticas públicas relacionadas ao campo e suas implicaçóes. Aqui, pode-se, mais claramente, reconhecer o movimento de caminhar entre a identificação do problema, a construção de uma problemática e o compromisso com a busca de solução. Por fim, também em 2015, Bernardo Kucinski acompanhado dos mais variados autores, desde intelectuais, militantes de direitos humanos, policiais até parlamentares, publica Bala Perdida: a violência policial no Brasile os desafios para sua superação. Nessa coletânea, uma vez mais, tem-se um projeto político-acadêmico cuja intenção é levar ao leitor uma variedade de evidências que subsidiem o desejo de transformação da realidade vigente: achados de pesquisa, denúncias, revelaçóes e proposiçóes combinam-se nessa aventura de saber para mudar.

Em síntese, os/as livros/coletâneas citados/as possuem expectativas e abordagens das mais diversas. Alguns vocacionados em contar a história do campo, outros em aprofundar e criar novas temáticas; outros em amplificar vozes autorizadas a falar sobre a polícia, a denunciar a polícia, a narrar sobre sua história no contexto brasileiro. Entre a preocupação de se fazer um balanço da produção existente e o relato de experiências e trajetórias, a produção editorial revela que, nos últimos anos, a polícia e suas questóes foram se deslocando da periferia discursiva para disputar alguma centralidade nas narrativas acadêmicas. E não sem razão. Como temos insistido, o campo emergente dos estudos policiais gravita em torno da sua caracterização como problema social, de seu reconhecimento como problemática sociológica e de sua relevância pela urgência de solução política no Brasil. Se, de fato, trata-se de saber para controlar, de conhecer para governar, então as polícias emergem como um ator institucional fundamental no processo de reforma do sistema de segurança pública e justiça. Afinal, são elas que administram, mais imediatamente, as inseguranças e violaçóes dos e sobre os outros, e sua própria exposição ao risco.

\section{A natureza dos textos e quem os escreve}

Optamos por dividir os estudos em duas grandes categorias: os acadêmicos e os institucionais. Com essa divisão, identificou-se um universo de 374 trabalhos acadêmicos e 26 institucionais. A primeira categoria compreende produçóes tanto individuais quanto coletivas elaboradas por pesquisadores(as) da área. Entre os textos assim classificados estão aqueles que tratam de resultados de pesquisas, bem como de revisôes teóricas e bibliográficas e que estão contidos no amplo espectro de revistas, livros, dissertaçóes e teses consultadas.

A segunda categoria diz respeito aos trabalhos de organizaçôes governamentais, não governamentais, internacionais e movimentos sociais. Registre-se que as publicaçôes classificadas como textos institucionais revelam o papel estratégico desempenhado pelas ONGs (nacionais e internacionais), grupos de pesquisa, movimentos sociais e organismos internacionais, pois 20 dos 26 trabalhos são assinados por instituiçóes dessa natureza. As demais são produçôes do Legislativo, do Ministério Público e das próprias instituiçóes policiais. Como imaginávamos, a maior parte dos trabalhos publicados pelas ONGs, movimentos sociais, grupos de pesquisa e organismos internacionais está voltada ao monitoramento e denúncia dos desvios de conduta policial (13 títulos), em especial a violência policial e/ou o uso excessivo de força, seguidos de estudos sobre modalidades de policiamento ( 6 títulos) e um informe sobre polícia e relaçóes raciais. 
Identificou-se, na coleta de dados, um tipo particular de produção que fala sobre a polícia e que não se enquadra nem entre os acadêmicos nem entre os institucionais, mas que foram igualmente interessantes de serem mapeados. Trata-se de tipo distinto de colaboração em que os autores constroem sua legitimidade pelo trânsito entre o universo policial, político e acadêmico. É a partir desses lugares de fala que os autores descrevem e analisam suas próprias experiências, e cuja condição, seja como nativo, seja como porta voz do real, empresta um status diferenciado às proposiçôes enunciadas. Neste quesito estão os trabalhos elaborados por Luiz Eduardo Soares (2000a); Carlos Magno Nazareth Cerqueira (2001); Luiz Eduardo Soares, Celso Athayde e MV Bill (2005); Luiz Eduardo Soares, Eduardo Batista e Rodrigo Pimentel (2006) e José Mariano Beltrame (2014). Tais obras, ora de caráter ficcional, ora relatos de "boas práticas", ora formas documentais de denúncia passaram a emergir no campo como um tipo de narrativa fundada na vivência ("eu vivi na pele") e na bagagem adquirida ("eu já passei por isso"). Uma e outra alegoria apontam para outra forma de descrever, valorizando o lugar de sujeito do narrador ante a realidade narrada e, com isso, seus atributos singulares - por exemplo, a disposição diante da resistência da vontade política no enfrentamento de um mundo sentido como mais real que a realidade. Mais principiológica do que sociológica, apresenta-se como uma narrativa de verdade, que se constrói pela empatia com as histórias de vida e seus percalços, generalizando-se pela conversão aos valores ali professados. Contudo, estas sagas discursivas, sob o feitio de liçóes de vida, parecem contribuir sobremaneira para emprestar visibilidade à temática policial. Por um lado, se colocam como reveladoras dos "bastidores" da segurança pública. Por outro, como guias e receitas para gestão e formulação de políticas.

Quanto aos textos acadêmicos, foi possível identificar minimamente o perfil de quem escreve, quem são e os trânsitos que fazem entre academia-polícia-governo, tal como indicado na introdução deste artigo.

Dos textos acadêmicos assinados individualmente, identificamos 56 escritos por homens e 33 por mulheres. Já em relação ao universo total, 342 eram assinados por não policiais, 22 por policiais e 6 elaborados conjuntamente por policiais e não policiais. Olhar para essa dimensão permite colocar em relevo a presença cada vez maior de policiais produzindo trabalhos técnicos e acadêmicos em diálogo e no interior das ciências sociais brasileiras ${ }^{32}$.

Observa-se hoje que muitas representaçóes sociais do mundo da polícia foram de alguma forma deslocadas como categorias analíticas e descritivas nos trabalhos acadêmicos, por exemplo as imagens "ciclo completo de polícia", "policiamento ostensivo", "policiamento preventivo", "policiamento investigativo", "uso progressivo da força" etc. Da mesma forma que expressóes do jargáo acadêmico passaram a fazer parte do repertório de policiais que ingressaram na universidade, tais como "relativizar", "ressignificar", "gestão do conhecimento e da informação", "administraçáo de conflitos" etc.

Quanto à distribuição regional ${ }^{33}$, as publicaçôes ainda estáo concentradas em São Paulo,

32 Vale considerar que os "policiais entram em cena" como interlocutores privilegiados no final dos anos 1990. Destaca-se a colaboração pioneira do Coronel da PM Carlos Magno Nazareth Cerqueira, comandante geral da Polícia Militar do Estado do Rio de Janeiro durante os dois governos Brizola (1983-1986; 1991-1994). Consultar Hollanda (2005).

33 Do universo total de 386 trabalhos, 236 são da região Sudeste, 70 do Centro-Oeste, 42 do Sul, 38 do Nordeste e nenhum foi encontrado para a região Norte. 
Rio de Janeiro, Brasília e Porto Alegre, além de Fortaleza e Salvador, que não por acaso reúnem os principais centros de pesquisa da área e as organizaçóes não governamentais mais antigas nos estudos policiais e melhor estruturadas na área de justiça criminal e segurança pública. Pode-se inferir que tais estados concentram não só as publicaçôes de maior relevância na área como os principais acessos às linhas de fomento disponíveis para os estudos policiais. Há que também salientar que Rio de Janeiro e São Paulo protagonizaram durante os anos de 1990 os primeiros lugares no ranking dos crimes contra a vida, além da ocorrência de eventos trágicos e emblemáticos como as chacinas e os episódios de brutalidade policial que tiveram repercussão nacional e internacional. No que diz respeito à abrangência dos estudos, propusemos avaliar se eram estudos (1) nacionais; (2) regionais (envolvendo comparação entre diferentes estados); (3) estaduais; (4) locais; ou (5) internacionais. Constatou-se que a maior parte dos trabalhos, 141 do total, trataram de dimensóes locais em seus objetos de análise. Em contrapartida, 49 estudos eram nacionais, resultado em grande medida de estudos encomendados pelo governo. Outros 48 apresentaram recortes estaduais e 12 regionais. Destaca-se que 112 trabalhos, $28 \%$ do total, não puderam ser classificados segundo sua abrangência territorial pois se referiam a estudos de natureza teórica ou de revisão de literatura.
Sobre o financiamento ${ }^{34}$ dos trabalhos, foi possível identificar se os estudos registrados faziam menção ao recebimento de recursos de instituições internacionais e nacionais. Como a referência do órgão financiador não é uma exigência obrigatória, é esperado que este recorte tenha elevada subnotificaçáo. De todo modo, foi possível apurar que os financiadores internacionais compreendem basicamente: a Open Society Foundation ${ }^{35}$, a Fundaçāo Ford ${ }^{36}$ e as agências da ONU. Já os nacionais foram financiados prioritariamente pelo Ministério da Justiça, através de açóes e editais promovidos pela Secretaria Nacional de Segurança Pública (Senasp). Como resultado, estáo os artigos contidos em Cadernos da Conferência Nacional de Segurança Pública (Conseg) e coletâneas organizadas pela Senasp ${ }^{37}$ com os resultados de pesquisas oriundas das ediçóes do edital Pensando a Segurança Pública, por exemplo.

Destaca-se ainda que os anos de 2013 e 2016 foram responsáveis por grande número de produçóes sobre o tema Polícia no Brasil. Em 2013, ocorreu a publicação dos resultados da $1^{\text {a }}$ edição do Edital Pensando a Segurança Pública, bem como o Termo de Cooperação firmado entre o Ministério da Justiça e o Fórum Brasileiro de Segurança Pública. Também é nesse ano que o Governo Federal cria o Plano Nacional de Prevenção a Violência contra a Juventude Negra (Plano Juventude Viva) e o Plano Nacional pela

34 Lembramos que só foi possível identificar os financiadores nos trabalhos que explicitamente fizeram esse crédito. Ponderamos, todavia, que a maior parte das produçōes em artigos (frutos de pesquisa de mestrado e doutorado) ou das próprias teses e dissertaçôes podem ter sido financiadas pelas principais agências de fomento do país: CAPES e CNPq.

35 A coletânea Polícia, Estado e sociedade: práticas e saberes latino-americanos e pesquisas e publicaçôes do Fórum Brasileiro de Segurança Pública, em especial a Revista Brasileira de Segurança Pública, contaram com o apoio da Open Society.

36 Por exemplo: coleção "Polícia e Sociedade" (NEV-USP), pesquisas e publicaçôes do Fórum Brasileiro de Segurança Pública, em especial a Revista Brasileira de Segurança Pública, e o livro Crime, polícia e justiça no Brasil (2014), relatórios de ONGs entre outros.

37 Sobre os editais e publicaçôes da Senasp - Ministério da Justiça, ver: seguranca/seguranca-publica/analise-e-pesquisa/ acervo/publicaçōes. 
Redução de Homicídios, que jamais foi implementado. Já em 2016 foram publicados os dossiês da Revista Brasileira de Segurança Pública e da revista Civitas, descritos na seção anterior deste trabalho.

\section{Sobre o que se escreve}

Conforme já mencionado nas notas metodológicas, o trabalho de classificação e apreciaçáo dos temas abordados nos distintos estudos consultados resultou numa lista inicial de 37 categorias que, depois de refinadas, transformaram-se em $19^{38}$. Reforçamos aqui o argumento de que o exercício classificatório implica necessariamente em aproximaçôes, interpretações e escolhas dos autores. Como tal, reconhecemos as dificuldades e fragilidades que as categorias podem conter. Se, por um lado, o repertório classificatório proposto admite redundâncias, por outro, permite interseção e sobreposição temáticas. Entende-se tal possibilidade como rentável, uma vez que favorece a oportunidade de múltipla entrada de um mesmo trabalho, o que permite investigar as fronteiras, as contiguidades e as descontinuidades entre assuntos. Entendese, portanto, como reveladoras das múltiplas interfaces existentes, da polissemia que delas emergem e das ambivalências nelas contidas. Por fim, buscou-se ainda aproximar as alternativas classificatórias dos assuntos e questóes mais recorrentes na literatura internacional dedicada aos estudos policiais. ${ }^{39}$

A Tabela 1 sintetiza o repertório de assuntos, temas e questóes que o campo emergente dos estudos policiais nas ciências sociais nos revelou.
Tabela 1

Distribuição dos temas por categorias agregadas

\begin{tabular}{|c|c|}
\hline Temas & $\begin{array}{l}\text { Número de } \\
\text { publicaçóes }\end{array}$ \\
\hline $\begin{array}{l}\text { Cultura organizacional e saberes e } \\
\text { práticas policiais }\end{array}$ & 81 \\
\hline $\begin{array}{l}\text { Modalidades de policiamento e } \\
\text { relaçōes interagências }\end{array}$ & 47 \\
\hline $\begin{array}{l}\text { Formas de controle da açáo policial; } \\
\text { mecanismos de responsabilizaçáo; } \\
\text { accountability e deontologia policial }\end{array}$ & 44 \\
\hline Desvios de conduta & 42 \\
\hline $\begin{array}{l}\text { Arquitetura e/ou modelo } \\
\text { institucional, abordagens } \\
\text { administrativas e inovaçôes } \\
\text { organizacionais }\end{array}$ & 25 \\
\hline $\begin{array}{l}\text { Mandato policial, força pública e } \\
\text { poder de polícia }\end{array}$ & 20 \\
\hline Reforma das polícias & 19 \\
\hline História das polícias & 16 \\
\hline $\begin{array}{l}\text { Condiçôes de trabalho, saúde e } \\
\text { segurança ocupacional }\end{array}$ & 15 \\
\hline $\begin{array}{l}\text { Formação e qualificação } \\
\text { profissional }\end{array}$ & 15 \\
\hline Polícia e relaçōes raciais & 14 \\
\hline $\begin{array}{l}\text { Polícia, relaçôes de gênero e } \\
\text { orientaçấo sexual }\end{array}$ & 11 \\
\hline Revisão de literatura & 11 \\
\hline $\begin{array}{l}\text { Políticas da polícia; governança } \\
\text { policial; gestấo do conhecimento }\end{array}$ & 11 \\
\hline Uso da força e armamentos & 9 \\
\hline $\begin{array}{l}\text { Confiança, imagem da polícia e } \\
\text { relaçōes comunitárias }\end{array}$ & 8 \\
\hline Padróes de desempenho policial & 5 \\
\hline Sindicatos, associaçóes e ativismos & 4 \\
\hline Policiamentos privados & 3 \\
\hline TOTAL & 400 \\
\hline
\end{tabular}

Fonte: Elaboração própria

38 Dentre as dezenove temáticas está "revisão de literatura”, que reúne os trabalhos seminais que serviram de base para o desenvolvimento da primeira parte do artigo.

39 Tomou-se como referência os seguintes títulos internacionais, referenciais do campo: Newburn (2005), Klockars; Stephen (1991), Maguire; Morgan; Reiner (2007), Kappeler (1999). 
Como se pode notar, alguns temas são mais recorrentes, outros nem tanto. Falaremos um pouco mais sobre cada um deles. A maior concentração de trabalhos gira em torno de questóes relacionadas à cultura organizacional. É neste guarda-chuva que estão abrigados trabalhos relacionados às visóes de mundo, às práticas e saberes policiais, às representaçôes sociais e identidades profissionais, às moralidades, às lógicas de funcionamento, aos rituais e ao ethos policial. Dentre os trabalhos encontrados destacam-se: Cerqueira (2001); Moretzohn (2001); Sadek e Arantes (2003); Nascimento (2011, 2014); Caruso (2004, 2015, 2016); Ramos e Musumesci (2005); Silva (2009); Caruso, Muniz e Blanco (2007); Suassuna (2013); Porto (2004); Poncioni (2004); Albernaz (2010, 2015); Ratton e Torres (2009); Macedo (2012); Muniz (2012a); Alvito (2013); Ribeiro e Machado (2014); Oliveira (2015); Azevedo e Vasconcelos (2011); Misse (2011); Kant de Lima (2011); Soares et al. (2012); Machado e Porto (2015); Mourão et al. (2016); Alcadipani e Medeiros (2016); Oliveira Neto (2016); Barbosa (2016) e Rodrigues et al. (2017). Nesse universo, as pesquisas empíricas ganham aqui centralidade. Reúnem-se, prioritariamente, estudos etnográficos e pesquisas que exploram métodos e técnicas qualitativas, principalmente entrevistas em profundidade com policiais interessados, realizadas fora das polícias e nos horários de folga, como uma estratégia de contorno às resistências corporativas ao trabalho de pesquisa independente que por vezes se manifestam. Há também estudos com uma abordagem quantitativa, porém menos expressivos que aqueles que lançam mão da observação e da interlocução com os policiais. Vale destacar que é nesse universo temático que identificamos autores que são pesquisadores nativos, isto é, policiais que, a partir de seu olhar e inserção privilegiados, descortinam o que acreditam ser o universo da polícia que deve ser conhecido pelos outros, trazendo para a cena acadêmica as etnografias policiais, um híbrido de autopoiese, exegese e catarse descritivo-analítica que explora a condição existencial de sujeito e objeto de reflexão (G. SILVA, 2009; R. SILVA, 2009; STORANI, 2008).

$\mathrm{O}$ segundo grande tema compreende o universo de modalidades de policiamento e as relaçóes interagências. Os estudos nesta temática foram inaugurados na década de 1990, com os primeiros trabalhos empíricos sobre polícia comunitária $^{40}$ e polícia de proximidade. No período investigado, ampliou-se significativamente o interesse por esse tema, sobretudo em razão do fato de que a implantação de programas de polícia comunitária, que contou com financiamento federal desde o primeiro governo de Fernando Henrique Cardoso, virou uma espécie de mantra político de governos que traziam um discurso progressista, porém objetivavam fazer intervençóes pontuais e de baixo custo nas estruturas policiais. Destaca-se a publicação em português de dois livros que se tornaram referências na discussão: Policiamento comunitário (BAYLEY; SKOLNICK, 2000); Padróes de policiamento (BAYLEY, 2001) e Policiando uma sociedade livre (GOLDSTEIN, 2003) ${ }^{41}$. O Núcleo de Estudos da Violência (NEV/USP) dedica-se à publicação de uma série de trabalhos (BRITO, 2003; NEME, 2003) sobre policiamento comunitário, assim como o Centro

40 O pioneiro projeto de policiamento comunitário desenvolvido pela Polícia Militar do Estado do Rio de Janeiro, no bairro de Copacabana, entre setembro de 1994 e julho de 1995, resultou num dos primeiros trabalhos escritos sobre o assunto. Consultar: Musumeci et al. (1996). Disponível em: <https://www.ucamcesec.com.br/textodownload/ seguranca-publica-e-cidadania-a-experiencia-de-policiamento-comunitario-em-copacabana-1994-95-relatorio -final-do-monitoramento-qualitativo/>. Acesso em: 13 abr. 2018. 
de Estudos de Criminalidade e Segurança Pública (Crisp/UFMG) (UNIVERSIDADE FEDERAL DE MINAS GERAIS, 2009). Evidencia-se o quanto os programas de policiamento comunitário - e foram tantos quantos os compromissos eleitorais - tornaram-se uma espécie de receita padráo prescrita para todo tipo de problema policial descrito. E isto de tal forma que o debate entre gestores, operadores e pesquisadores no final da década de 1990 tinha como ponto convergente a chamada "comunitarização" da polícia, e como ponto de dissenso a definição da polícia comunitária enquanto uma "filosofia de polícia" ou uma "estratégia de policiamento".

Um segundo grupo de investigaçóes sobre modalidades de policiamento dedicou-se a descrever e analisar experiências voltadas à inovação quanto a formas de organizar o policiamento, como os trabalhos de Dias Neto (2002); Mesquita Neto (2004); Neves (2005); Oliveira Júnior (2007); Sales, Alencar e Feitosa (2009); Tavares dos Santos et al. (2013); Muniz e Proença Junior (2007a); Ribeiro e Montandon (2015); Silva e Ribeiro (2015); Silva (2015) e Poncioni (2016). Noutra frente, destacaram-se os estudos sobre policiamento em favelas ou áreas de risco. Estudos sobre grupamentos em áreas especiais (RJ), grupamentos em áreas de risco (MG) e, finalmente, sobre Unidades de Polícia Pacificadora (RJ) ganharam relevância ${ }^{42}$, como os trabalhos de Albernaz, Caruso e Moraes (2007); Malaguti Batista (2015); Cano (2012); Macedo (2012); Oliveira (2015); Vieira (2014); Machado da Silva (2015); Menezes (2015); Muniz e Mello (2015); e Muniz e Albernaz (2015).

O terceiro tema mais presente trata do controle da ação policial, surgindo como o fio condutor para os estudos sobre os dispositivos de controle interno e externo, a exemplo das análises sobre corregedoria, ouvidoria e o papel do Ministério Público (BEATO FILHO, 2004; BRAGA, 2006; LEMGRUBER; MUSUMECI; CANO, 2003; LEMGRUBER et al., 2016; LIMA, 2008; MACHADO, 2011; MUNIZ; PROENÇA JÚNIOR, 2007b, 2013; REVISTA DO CNMP, 2011; SILVA, 2008; ZAVERUCHA, 2008). Também repousam aqui os ainda poucos trabalhos brasileiros nas ciências sociais sobre deontologia e ética policial (CANO, 2013; COSTA; PORTO, 2011; GRECCO, 2012; SILVA, 2008).

Alguns autores investiram em discussôes teóricas sobre os mecanismos de responsabilizaçấo e accountability, bem como estudos que propusessem modelos de controle da ação policial, entre eles: Costa (2004a); Muniz e Proença Júnior (2007b, 2013); Barreira (2008); Oliveira (2010); Proença Júnior, Muniz e Poncioni (2009), por exemplo, investem particularmente na construção de uma teoria de polícia e dos policiamentos explorando a construçáo conceitual do mandato policial, do uso da força e suas implicaçóes.

Já os estudos sobre desvios de conduta, que aparecem entre os quatro principais assuntos, estão associados, por óbvio, ao controle da ação policial, todavia, optamos por analisá-los em separado, táo somente para explicitar seu destaque entre os registros que encontramos. Aqui residem os estudos sobre violência policial e, em menor grau, aqueles sobre corrupção policial. É no universo de estudos assim categorizados que estão grande parte dos relatórios de pesquisa, informes e livros produzidos por ONGs, movimentos sociais, organismos governamentais e internacionais. Destacam-se os trabalhos de Oliveira, Ribeiro e Zanetti (2000); Justiça Global $(2001,2004)$ e Alston (2008).

42 Esses trabalhos surgem no contexto das políticas públicas estaduais de segurança. Casos de Minas Gerais, com políticas como Fica Vivo; Rio de Janeiro, com a Política de Pacificação; e Pernambuco, com o Pacto Pela Vida. 
Também localizamos trabalhos sobre a conduta dos agentes policiais, as práticas de abordagem e o padrão de interrogatórios policiais (ANISTIA INTERNACIONAL, 2005, 2015; CONECTAS, 2017; JUSTIÇA GLOBAL, 2010, 2015; MACHADO; NORONHA, 2002b; SÁ, SANTIAGO NETO, 2011) e sobre vitimização e letalidade da ação policial (ADORNO et al., 2008; CUBAS, 2013; LOPES, 2013; MISSE, 2011; OLIVEIRA JÚNIOR, 2007; RIBEIRO; OLIVEIRA, 2013; RIO DE JANEIRO, 2009; SINHORETTO et al., 2013; SOARES; MOURA; AFONSO, 2009; VIANA; FARIAS, 2011). Trabalhos dedicados à discussão clássica sobre as causas da violência policial também foram mapeados, como os desenvolvidos por Belli (2004); Battibugli (2009); Bueno (2014); Cubas, Natal e Castelo Branco (2015) e Zaccone (2015).

Numa mescla de referências que reúne desde estudos de envergadura teórica e empírica até relatos e denúncias de violaçôes policiais, o tema desvio de conduta continua mobilizando tanto os intelectuais das ciências sociais quanto os integrantes da sociedade civil organizada. Aqui, melhor que em qualquer outra temática, tem-se o encontro nem sempre conciliatório entre o engajamento acadêmico e militante. É precisamente nesta temática que as possíveis ambiguidades trazidas pelo prescrever com a aparência do descrever arriscam-se a ser mais proeminentes. E, por sua vez, é onde, no calor do debate público sobre as violaçôes policiais, tem-se a proliferação de lugares de fala e seus embates em torno da verdade da, sobre e contra as vítimas, e da verdade da, sobre e contra a polícia.

Além dos temas enfatizados acima, existem outros que aparecem de forma menos expressiva ao longo do período investigado, ainda que se relacionem diretamente com aqueles mais atrativos aos pesquisadores. Neste universo encontramos trabalhos que levantam a discussão sobre estrutura e organização das polícias a partir de estudos acerca da arquitetura elou modelo institucional dos meios de força policiais, como os trabalhos de Soares (2000a, 2003, 2006, 2007, 2012); Machado da Silva (2009); Bicudo (2000); Brasil e Abreu (2002); Medeiros (2004); Beltrame (2014); reforma das polícias (AZEVEDO; NASCIMENTO, 2016; BEATO; RIBEIRO, 2016; CARUSO, ALBERNAZ; MORAES, 2006; COSTA, 2004b, 2008; LIMA; BUENO; SANTOS, 2014; SOZZO; AZEVEDO, 2016) e, em menor frequência, sobre policiamentos privados (HUGGINS, 2010; LOPES, 2011, 2013).

Em relação aos dois primeiros temas é também notória a influência da agenda governamental, por exemplo, na agenda de pesquisas da área. Lembremos que o tema da arquitetura institucional esteve na ordem do dia da Secretaria Nacional de Segurança Pública no primeiro quinquênio dos anos $2000 \mathrm{com}$ as discussôes sobre o chamado Sistema Único de Segurança Pública (Susp) ${ }^{43}$.

Na esfera dos trabalhos sobre sociologia da força pública inscrevem-se aqueles dedicados à discussão sobre mandato policial e poder policial (ADORNO; DIAS, 2014; BRODEUR, 2004; MONJARDET, 2003; MUNIZ; MELLO, 2015; MUNIZ; PROENÇA JÚNIOR, 2007b, 2014b; MUNIZ; SILVA, 2010; SOUZA, 2001) e um outro conjunto dedicado à história das polícias (BATTIBUGLI, 2009; BRETAS; ROSEMBERG, 2013; CUNHA; CUNHA, 2013; GUERRA, 2016; SOARES; ROLIM; RAMOS, 2009).

43 Em 20 de dezembro de 2016 foi aprovado, pela Comissáo de Segurança Pública e Crime Organizado da Câmara, o Projeto de Lei no 3.734/12, que cria o Sistema Único de Segurança Pública (SUSP), até o momento não implementado e regulamentado. 
Observa-se, ainda, debates sobre as condiçôes de realização do trabalho policial, a capacitação e parametrização das açôes dos profissionais da segurança pública e os critérios de avaliação $e$ mensuração da atividade policial. Neste conjunto de temas localizamos trabalhos sobre: condiçōes de trabalho, saúde e segurança ocupacional (ADORNO; MINAYO, 2013; ALCÂNTARA JÚNIOR, 2007; BEZERRA; MINAYO; CONSTATINO, 2013; BITTNER, 2003; CASTRO; CRUZ, 2015; FERNANDES, 2016; LIMA; RATTON; AZEVEDO, 2014; PEREIRA, 2015; PONCIONI, 2014; ROMÃO, 2016; RUDNICKI, 2008).

Outro conjunto de trabalhos encontrados dedicaram-se ao tema da formação e qualificação profissional, tais como: Muniz (2001); Sá (2002); Barreira e Brasil (2002); Balestreri (2003); Caruso (2004); Poncioni (2005); Sanches e Souza (2008); Pinc (2011); Tavares dos Santos et al. (2013); Pinto et al. (2014) e Caruso et al. (2016). Outros trabalhos relevantes trataram dos padróes de desempenho policial, por exemplo: Brodeur (2000); Monjardet (2001); Muniz e Proença Júnior.

Destacam-se ainda alguns estudos sobre políticas da polícia, governança policial e gestão do conhecimento, bem como sobre o uso da força e armamentos. Nesse conjunto encontram-se os trabalhos de Paes Machado e Noronha (2002); Albernaz, Ribeiro e Luz (2009); Storani (2009); Dias Neto (2013) e Musumeci (2015). Há também aqueles que tratam sobre sindicatos, associaçôes e ativismos, que particularmente nos últimos anos começam a surgir. Dentre eles estão Archanjo (2008); Ramos e Paiva (2009); Berlatto, Codato e Bolognesi (2016).

Por fim, verifica-se ainda um conjunto de trabalhos sobre relaçōes raciais, de gênero e orientação sexual que aborda questóes sobre o perfil étnico-racial dos integrantes das forças policiais e as relaçóes do ponto de vista racial (RAMALHO NETO, 2012; SANSONE,
2002), sexual (FRANÇA, 2016) e de gênero (BUENO et al. 2015; MOREIRA, 2016; SANTANA, 2015; SOARES; MUSUMECI, 2005). Neste conjunto temático revela-se uma ênfase nas pesquisas que tratam das relaçóes das polícias com os grupos sociais em situação de vulnerabilidade e historicamente discriminados (BUENO et al., 2016; MELLO; VALENÇA, 2016), em especial os estudos sobre abordagem policial e filtragem racial (BARROS, 2008; DUARTE et al., 2014; REIS, 2001, 2002; SINHORETTO et al., 2013). Cabe reiterar que neste recorte temático encontram-se os estudos que exploram o preconceito, a discriminação, a violência policial, as formas de resistência e a luta das vítimas da ação policial. Todavia, há ainda um caminho a percorrer que explore de forma substantiva a natureza estrutural do racismo, do sexismo, da lesbo-trans-homofobia e dos seus impactos nas formas de organização e funcionamento das polícias no Brasil e, por conseguinte, os seus efeitos na vitimização policial.

\section{Considerações finais}

A esta altura mostra-se oportuno fazer breves consideraçóes sobre algumas questôes que propusemos levantar e que, obviamente, não se esgotam aqui. Sáo, antes de tudo, possibilidades para aprofundar o entendimento sobre $\mathrm{o}$ campo dos estudos policiais que propomos dar a conhecer a partir da distribuição dos interesses dos pesquisadores(as) pelo repertório temático proposto neste artigo. $\mathrm{O}$ primeiro ponto a ser mencionado diz respeito ao fato de que o tema das práticas policiais desviantes é reapresentado na temática da cultura policial. E isto em parte parece dizer respeito a uma certa visáo estática da cultura policial, que em certos estudos aparece somente caracterizada por atributos negativos, ou seja, pelos efeitos perversos da ação policial. Revela-se uma concepção de cultura tão naturalizada, substantiva e reificada, que a 
violência e a corrupção aparecem como algo endêmico, e mesmo inerente, aos lugares de polícia. Assim, a cultura policial é naturalmente vista como uma entidade táo homogênea $\mathrm{e}$ uniforme que se pode visualizar uma "cultura da guerra" ou uma "cultura do confronto" que definiria uma organização complexa como a polícia. Eis aqui anunciado o risco de se adotar, por força da descrição prescritiva, as representaçôes nativas como representaçóes conceituais: arrisca-se a aceitar como explicaçáa o que se apresenta como denúncia social e, sobretudo, como álibi dos discursos policiais contrários às reformas. Afinal, se o problema da polícia é a sua cultura, e se a cultura tende a ser imutável, então há que projetar a mudança para uma vontade de futuro expressa na utopia de uma sociedade sem dispositivos de controle.

Um outro ponto que merece atenção refere-se ao fato de que os temas de maior interesse parecem também aqueles que apontam para o desafio de descrever subsídios para prescrever alguma transformação. Em seu conjunto estes temas são aqueles que trariam soluçóes para as graves questôes: em resposta às violaçôes dos direitos humanos, ao descontrole da açáo policial, ao despreparo profissional, ao aumento da criminalidade violenta e à insegurança, há que compreender e propor reformas na cultura policial, na formação corporativa, nos modelos de policiamento etc.

Tem-se a impressão que uma das principais motivaçóes dos pesquisadores brasileiros tem sido investigar atendendo às demandas do debate público. Neste sentido, parecem mais interessados em mapear os problemas da polícia do que a polícia em si. Daí observar uma disposiçẫo mais acentuada para produzir uma ciência social aplicada à polícia, o que melhor atenderia à urgência por reformas no tempo presente do que a construção de uma ciência social da polícia, cuja temporalidade ultrapassa os apetites cidadáos pela democratização das organizações policiais.

\section{Referências}

ABREU, S. R. et al. Transição de uma polícia de controle para uma polícia cidadã. São Paulo em perspectiva, São Paulo, v. 18, n. 1, p. 119-131, 2004.

ABREU, V. C. Segurança pública e direitos humanos: um estudo na sociedade democrática brasileira. In: LIMA, C.; BAPTISTA, G.; FIGUEIREDO, I. S. (Orgs.). Segurança pública e direitos humanos: temas transversais. Brasília, DF: Ministério da Justiça; Senasp, 2013. p. 9-82.

ADORNO, S. A criminalidade urbana violenta no Brasil: um recorte temático. Revista Brasileira de Informação Bibliográfica em Ciências Sociais, São Paulo, n. 35, p. 3-24, 1993.

Monopólio estatal da violência na sociedade brasileira contemporânea. In: MICELI, S. (Org.). O que ler na ciência social brasileira (1970-2002). São Paulo: Anpocs, 2001. v. 4, p. 167-207.

ADORNO, S.; DIAS, C. N. Monopólio estatal da violência. In: LIMA, R. S.; RATTON, J. L.; AZEVEDO, R. G. (Orgs.). Crime, polícia e justiça no Brasil. São Paulo: Contexto, 2014. p. 187-198.

ADORNO, S.; MINAYO, M. C. S. Risco e (in)segurança na missão policial. Ciência e Saúde Coletiva, Rio de Janeiro, v. 18, n. 1, p. 585-593, 2013. 
ADORNO, S. et al. Homicídios, desenvolvimento socioeconômico e violência policial no Município de São Paulo, Brasil. Revista Panamericana de Salud Publica, Washington, v. 23, n. 4, p. 24-56, 2008.

ALBERNAZ, E. Na fronteira entre o bem e o mal: ética profissional e moral religiosa entre policiais militares evangélicos cariocas. Caderno CRH, Salvador, v. 23, n. 1, p. 525-539, 2010.

Sobre legitimidade, produtividade e imprevisibilidade: seletividade policial e a reprodução da ordem social no plano de uma certa "política do cotidiano". Confluências, Niterói, v. 17, n. 1, p. 109-122, 2015.

ALBERNAZ, E.; CARUSO, H.; MORAES, L. P. B. Tensóes e desafios de um policiamento comunitário em favelas do Rio de Janeiro: o caso do Grupamento de Policiamento em Áreas Especiais. São Paulo em Perspectiva, São Paulo, v. 21, n. 2, p. 39-52, 2007.

ALBERNAZ, E.; RIBEIRO, L.; LUZ, D. Uso progressivo da força: dilemas e desafios. In: STORANI, P. (Org.). Uso progressivo da força: um protocolo de atendimento. Brasília, DF: Ministério da Justiça, 2009. p. 12-15.

ALBUQUERQUE, C. L.; PAES MACHADO, E. Sob o signo de marte: modernização, ensino e ritos da instituição policial militar. Sociologias, Porto Alegre, v. 3, n. 5, p. 141-237, 2001.

ALCADIPANI, R.; MEDEIROS, C. O. Herói-envergonhado: tensôes e contradiçôes no cotidiano do trabalho policial. Revista Brasileira de Segurança Pública, São Paulo, v. 10, n. 2, p. 134-153, 2016.

ALCÂNTARA JÚNIOR, A. Cultura e atitudes ocupacionais entre policiais militares em Belo Horizonte. 2007. 212 f. Tese (Doutorado em Ciências Humanas) - Universidade Federal de Minas Gerais, Belo Horizonte, 2007.

ALSTON, P. Relatório do relator especial de execuções extrajudiciais, sumárias ou arbitrárias: adendo Missão ao Brasil. Genebra: Conselho de Direitos Humanos, 2008.

ALVITO, M. Maçaranduba neles! torcidas organizadas e policiamento no Brasil. Tempo, Niterói, v. 19, n. 34, p. 81-94, 2013.

AMPARO-ALVES, J. À sombra da morte: juventude negra e violência letal em São Paulo, Rio de Janeiro e Salvador. Bahia Análise \& Dados, Salvador, v. 20, n. 2, p. 563-578, 2010.

. Topografias da violência: necropoder e governamentalidade espacial em São Paulo. Revista do Departamento de Geografia, São Paulo, v. 22, n. 1, p. 108-134, 2011.

ANISTIA INTERNACIONAL. Brasil: eles entram atirando: policiamento de comunidades socialmente excluídas. Londres: Anistia Internacional, 2005.

. "Você matou meu filho": homicídios cometidos pela polícia militar da cidade do Rio de Janeiro. Londres: Anistia Internacional, 2015.

ÁVILA, T. A. P. Estado democrático de direito e controle externo da atividade policial no Brasil. In: MACHADO, B. A. (Org.). Justiça criminal e democracia II. São Paulo: FSMPDFT; Marcial Pons, 2015. p. 381-417. 
ARAÚJO, A. F. "Não tem corpo, não tem crime": notas socioantropológicas sobre o ato de fazer desaparecer corpos. Horizontes Antropológicos, Porto Alegre, v. 22, n. 46, p. 37-64, 2016.

ARCHANJO, G. A massa da tropa: greve na polícia militar da Bahia, 1981. Salvador: Solisluna Design, 2008.

AZEVEDO, E. F. A polícia e suas polícias: clientela, hierarquia, soldado e bandido. Psicologia, Ciência e Profissão, Brasília, DF, v. 37, n. 3, p. 553-564, 2017.

AZEVEDO, R. G.; NASCIMENTO, A. A. Desafios da reforma das polícias no Brasil: permanência autoritária e perspectivas de mudança. Civitas, Porto Alegre, v. 16, n. 4, p. 45-57, 2016.

AZEVEDO, R. G.; VASCONCELOS, F. B. O inquérito policial em questão: situação atual e a percepção dos delegados de polícia sobre as fragilidades do modelo brasileiro de investigação criminal. Sociedade e Estado, Brasília, DF, v. 26, n. 1, p. 45-52, 2011.

AZEVEDO, R. G. et al. Denúncias de violência policial recebidas pelo Centro de Referência em Direitos Humanos da Defensoria Pública do Estado do RS. Revista da Defensoria Pública do Estado do Rio Grande do Sul, Porto Alegre, v. 17, n. 1, p. 151-171, 2017.

BALESTRERI, R. Direitos humanos: coisa de polícia. Passo Fundo: Capec, 2003.

BARBOSA, L. C. Cativando mentes e coraçôes dos "guardiôes da Ceilândia": as re-representaçôes sociais do $8^{\circ}$ batalhão da PMDF. 2016. 190 f. Dissertação (Mestrado em Sociologia) -Universidade de Brasília, Brasília, 2016.

BARBOSA, W. F.; SÁ, L. D. Redefiniçôes da condição de morador: classificações das clientelas no mandato policial e as suas consequências nas relações entre polícia e população. Caderno $C R H$, Salvador, v. 28, n. 75, p. 639-656, 2015.

BARREIRA, C. Questão de segurança: políticas governamentais e práticas policiais. Rio de Janeiro: Relume Dumará, 2004a.

Em nome da lei e da ordem: a propósito da política de segurança pública. São Paulo em Perspectiva, São Paulo, v. 18 , n. 1 , p. $77-86,2004 \mathrm{~b}$.

. O controle democrático das práticas policiais. Travessias, Cascavel, v. 1, p. 107-132, 2008.

BARREIRA, C.; ADORNO, S. A violência na sociedade brasileira. In: MARTINS, C. B.; MARTINS, H. H. T. S. (Orgs.). Horizontes das ciências sociais no Brasil. São Paulo: Barcarolla, 2010. v. 1, p. 303-374.

BARREIRA, C.; BRASIL, M. G. M. Academias de polícia e universidade: parcerias e resistências. Porto Alegre: Editora da UFRGS, 2002. p. 151-164.

BARROS, G. S. Filtragem racial: a cor na seleção do suspeito. Revista Brasileira de Segurança Pública, São Paulo, v. 3, n. 1, p. 134-155, 2008. 
BATTIBUGLI, T. A difícil adaptação da polícia paulista ao estado de direito (pós-1946 e pós-1985). Dilemas, Rio de Janeiro, v. 2, n. 3, p. 39-63, 2009.

BAYLEY, D. H. Padrōes de policiamento. São Paulo: Fundação Ford, 2001.

BAYLEY, D. H.; SKOLNICK, J. H. Policiamento comunitário. São Paulo: Fundação Ford, 2000.

BEATO FILHO, C. C. O papel da ouvidoria de polícia de Minas Gerais no controle externo da atividade policial. Belo Horizonte: Crisp, 2004. (Relatório de pesquisa).

BEATO FILHO, C. C.; RIBEIRO, L. Discutindo a reforma das polícias no Brasil. Civitas, Porto Alegre, v. 16, n. 4, p. 56-68, 2016.

BEATO FILHO, C. C.; SILVA, B. F. A.; TAVARES, R. Crime e estratégias de policiamento em espaços urbanos. Dados, Rio de Janeiro, v. 51, n. 3, p. 687-717, 2008.

BELLI, B. Violência policial e segurança pública: democracia e continuidade autoritária no Brasil contemporâneo. Impulso, Piracicaba, v. 15, n. 37, p. 17-34, 2004.

BELTRAME, J. M. Todo dia é segunda-feira. Rio de Janeiro: Sextante, 2014.

BERLATTO, F.; CODATO, A.; BOLOGNESI, B. Da polícia à política: explicando o perfil dos candidatos das Forças Repressivas de Estado à Câmara dos Deputados. Revista Brasileira de Ciência Política, Brasília, DF, v. 1, n. 21, p. 77-120, 2016.

BEZERRA, C. M.; MINAYO, M. C. S.; CONSTANTINO, P. Estresse ocupacional em mulheres policiais. Ciência e Saúde Coletiva, Rio de Janeiro, v. 18, n. 3, p. 657-666, 2013.

BICUDO, H. A unificação das polícias no Brasil. Estudos Avançados, São Paulo, v. 14, n. 40, p. 91-106, 2000.

BITTNER, E. Aspectos do trabalho policial. São Paulo: Edusp, 2003.

BOURDIEU, P. A economia das trocas simbólicas. 5. ed. São Paulo: Perspectiva, 2001. Economia das trocas linguísticas. São Paulo: Edusp, 2008.

BOURDIEU, P.; PASSERON, J.-C. A reprodução: elementos para uma teoria do sistema de ensino. 5. ed. Petrópolis: Vozes, 2011.

BRAGA, R. W. Arquiteturas organizacionais, modelos de gestão e indicadores de eficiência das corregedorias e ouvidorias de polícia. Brasília, DF: Ministério da Justiça, 2006. (Relatório final).

BRASIL, G. M.; ABREU, D. Uma experiência de integraçấo das polícias civil e militar: os distritos-modelo em Fortaleza. Sociologias, Porto Alegre, v. 4, n. 8, p. 318-355, 2002. 
BRETAS, M. L.; ROSEMBERG, A. A história da polícia no Brasil: balanço e perspectivas. Topoi, Rio de Janeiro, v. 14, n. 26, p. 162-173, 2013.

BRITO, A. S.; SOUZA, L. Representaçôes sociais de policiais civis sobre profissionalização. Sociologias, Porto Alegre, v. 6, n. 12, p. 304-327, 2004.

BRITO, E. O policiamento que a sociedade deseja: análise das discussóes em grupo com representantes da sociedade civil da regiāo do centro de São Paulo. São Paulo: Núcleo de Estudos da Violência, 2003. (Relatório).

. A ficção e a realidade: a imagem da polícia na literatura dos primeiros anos da República brasileira. Lingua e Letras, Cascavel, v. 8, n. 15, p. 119-129, 2007.

BRODEUR, J.-P. Como reconhecer um bom policiamento. São Paulo: Edusp, 2000.

Por uma sociologia da força pública: consideraçōes sobre a força policial e militar. Caderno $C R H$, Salvador, v. 17, n. 42 , p. $481-489,2004$.

BUENO, S. Bandido bom é bandido morto: a opção ideológico-institucional da política de segurança pública na manutenção de padrōes de atuação violentos da polícia militar paulista. 2014. 145 f. Dissertação (Mestrado em Administraçáa) - Fundação Getulio Vargas, São Paulo, 2014.

BUENO, S. et al. As mulheres nas instituiçôes policiais. São Paulo: Fórum Brasileiro de Segurança Pública, 2015. (Relatório de pesquisa).

. A polícia precisa falar sobre estupro: percepção sobre violência sexual e atendimento a mulheres vítimas de estupro nas instituições policiais. São Paulo: Fórum Brasileiro de Segurança Pública, 2016. (Relatório de pesquisa).

CABRAL, S.; BARBOSA, A. C. Q.; LAZZARINI, S. Monitorando a polícia: um estudo sobre a eficácia dos processos administrativos envolvendo policiais civis na Corregedoria Geral da Bahia. Organizaçóes e Sociedade, Salvador, v. 15 , n. 47 , p. $87-97,2008$.

CAMPOS, M.; ALVAREZ, M. Políticas públicas de segurança, violência e punição no Brasil (2000-2016). In: MARTINS, C. B.; MICELI, S. (Orgs.). Sociologia brasileira hoje. São Paulo: Ateliê, 2017. p. 143-216.

CANO, I. (Org.). Os donos do morro: uma avaliação exploratória do impacto das Unidades de Polícia Pacificadora (UPP’s) no Rio de Janeiro. São Paulo: Fórum Brasileiro de Segurança Pública; Rio de Janeiro: Laboratório de Análise da Violência, 2012.

. Análise comparativa das legislaçôes disciplinares das corporaçôes de segurança pública: uma proposta de matriz de lei disciplinar para o Brasil. In: LIMA, C.; BAPTISTA, G.; FIGUEIREDO, I. S. (Orgs.). Segurança pública e direitos humanos: temas transversais. Brasília, DF: Ministério da Justiça; Senasp, 2013. p. 303-402.

CANO, I.; DUARTE, T. As corregedorias dos órgãos de segurança pública no Brasil. Brasília, DF: Ministério da Justiça; Senasp, 2013. (Nota técnica). 
CARUSO, H. Das práticas e dos seus saberes: a construção do "fazer policial" entre praças da PMERJ. 2004. Dissertação (Mestrado em Antropologia) - Universidade Federal Fluminense, Niterói, 2004.

A ordem e a desordem de ontem e de hoje: notas etnográficas sobre a polícia na Lapa carioca. Civitas, Porto Alegre, v. 15, n. 1, p. 66-83, 2015.

Entre ruas, becos e esquinas: a construção da ordem na Lapa carioca. Brasília, DF: Editora da UnB, 2016.

CARUSO, H.; ALBERNAZ, E.; MORAES, L. A polícia que queremos: desafios para a reforma da Polícia Militar do Estado do Rio de Janeiro. Cadernos Adenauer, Rio de Janeiro, v. 3, p. 5-15, 2006.

CARUSO, H.; MUNIZ, J. O.; BLANCO, A. C. C. (Orgs.). Policia, estado e sociedade: saberes e práticas latino-americanos. Rio de Janeiro: Publit, 2007.

CARUSO, H. et al. Educação a distância em segurança pública no Brasil: um estudo sobre os efeitos Rede EAD-Senasp na trajetória dos seus discentes. In: PARESCHI, A. C. C. et al. (Orgs.). Investigaçâo criminal e avaliação de políticas de segurança pública. Brasília, DF: Ministério da Justiça, 2016. p. 215-256.

CASTRO, C. O espirito militar: um antropólogo na caserna. 2. ed. Rio de Janeiro: Zahar, 2004.

CASTRO, M. C. A.; CRUZ, R. M. Prevalência de transtornos mentais e percepção de suporte familiar em policiais civis. Psicologia, Ciência e Profissäo, Brasília, DF, v. 35, n. 2, p. 271-289, 2015.

CERQUEIRA, C. M. N. (Org.). O futuro de uma ilusão: o sonho de uma nova polícia. Rio de Janeiro: Freitas Bastos, 2001.

COMPARATO, B. K. As ouvidorias de polícia no Brasil: controle e participação. 2006. 262 f. Tese (Doutorado em Ciência Política) - Universidade de São Paulo, São Paulo, 2006.

CONECTAS DIREITOS HUMANOS. Tortura blindada: como as instituiçôes do sistema de justiça perpetuam a violência nas audiências de custódia. São Paulo: Conectas, 2017.

COSTA, A. T. M. Como as democracias controlam as polícias: os mecanismos institucionais de controle da atividade policial. Novos Estudos Cebrap, São Paulo, v. 70, n. 3, p. 65-78, 2004 a.

Entre a lei e a ordem: violência e reforma nas polícias do Rio de Janeiro e Nova York. Rio de Janeiro: FGV, 2004b.

A reforma nas polícias e seus obstáculos: uma análise comparada das interaçōes entre sociedade civil, sociedade política e as polícias. Civitas, Porto Alegre, v. 8, n. 3, p. 409-427, 2008.

COSTA, A. T. M.; LIMA, R. S. Segurança pública. In: LIMA, R.; RATTON, J. L.; AZEVEDO, R. G. (Orgs.). Crime, polícia e justiça no Brasil. São Paulo: Contexto, 2014. p. 482-490.

COSTA, A. T. M.; LIMA, R. S.; OLIVEIRA JÚNIOR, A. Novos padrōes de investigação policial no Brasil. Sociedade e Estado, Brasília, DF, v. 31, n. 1, p. 147-164, 2016. 
COSTA, A. T. M.; PORTO, M. S. G. Controlando a atividade policial: uma análise comparada dos códigos de conduta no Brasil e no Canadá. Sociologias, Porto Alegre, v. 13, n. 1, p. 342-381, 2011.

. Violência policial: abordagens da literatura. In: KUCINSKI, B. et al. (Eds.). Bala perdida: a violência policial no Brasil e os desafios para sua superaçáo. São Paulo: Boitempo, 2015. p. 103-110.

CUNHA, E. C.; CUNHA, A. S. Polícia Militar do Estado de Goiás (154 anos): história, memória e representaçôes. Revista Brasileira de Estudos em Segurança Pública, São Paulo, v. 5, n. 1, p. 56-69, 2013.

DIAS NETO, T. Policiamento comunitário e controle sobre a polícia: a experiência norte-americana. 2. ed. Rio de Janeiro: Lumen Júris, 2002.

. Regulações sobre o uso da força pelas polícias militares dos estados de São Paulo e Pernambuco. In: LIMA, C.; BAPTISTA, G.; FIGUEIREDO, I. S. (Orgs.). Segurança pública e direitos humanos: temas transversais. Brasília, DF: Ministério da Justiça; Senasp, 2013. p. 239-302.

DUARTE, E. et al. Quem é o suspeito do crime de tráfico de drogas? anotaçôes sobre a dinâmica de preconceitos raciais e sociais na definição das condutas de usuário e traficante pelos policiais militares nas cidades de Brasília, Curitiba e Salvador. In: LIMA, C.; BAPTISTA, G.; FIGUEIREDO, I. S. (Orgs.). Segurança pública e direitos humanos: temas transversais. Brasília, DF: Ministério da Justiça; Senasp, 2014. p. 81-118.

ERICSON, R. V.; KEVIN, D. H. Policing the risk society. Oxford: Oxford University Press, 1997.

FERNANDES, A. Vitimização policial: análise das mortes violentas sofridas por integrantes da Polícia Militar do Estado de São Paulo (2013-2014). Revista Brasileira de Segurança Pública, São Paulo, v. 10, n. 2, p. 192-219, 2016.

FRANÇA, F. G. Hierarquia da invisibilidade: preconceito e homofobia na formação policial militar. Revista Brasileira de Segurança Pública, São Paulo, v. 10, n. 2, p. 154-170, 2016.

GOLDSTEIN, H. Policiando uma sociedade livre. São Paulo: Fundação Ford, 2003.

GRECCO, R. Atividade policial: aspectos penais, processuais penais, administrativos e constitucionais. 4. ed. Niterói: Impetus, 2012.

GREENE, J. Administração do trabalho policial. São Paulo: Edusp, 2000.

GUERRA, M. P. Polícia e ditadura: a arquitetura institucional da segurança pública de 1964-1988. Brasília, DF: Ministério da Justiça, 2016.

HOLLANDA, C. B. Polícia e direitos humanos: política de segurança pública no primeiro governo Brizola. Rio de Janeiro: Revan, 2005.

HUGGINS, M. K. Violência urbana e privatização do policiamento no Brasil: uma mistura invisível. Caderno CRH, Salvador, v. 23, n. 60, p. 45-67, 2010. 
JUSTIÇA GLOBAL. Execuçôes sumárias, arbitrárias ou extrajudiciais: uma aprovação da realidade brasileira. Rio de Janeiro: Justiça Global, 2001.

Relatório Rio: violência policial e insegurança pública. Rio de Janeiro: Justiça Global, 2004.

Informe à relatora especial sobre os direitos da criança e do adolescente acerca dos autos de resistência, racismo e violência contra crianças e adolescentes no Rio de Janeiro. Rio de Janeiro: Justiça Global, 2015.

Informe à relatora especial sobre povos afrodescendentes sobre recentes violaçöes de direitos humanos cometidas pelo estado brasileiro contra a população de favelas e periferias da cidade do Rio de Janeiro. Rio de Janeiro: Justiça Global, 2016.

KANT DE LIMA, R. A polícia da cidade do Rio de Janeiro: seus dilemas e paradoxos. Rio de Janeiro: Forense, 1995.

Polícia e exclusão na cultura judiciária. Tempo Social, São Paulo, v. 9, n. 1, p. 23-34, 1997.

Administraçáo de conflitos, espaço público e cidadania: uma perspectiva comparada. Civitas, Porto Alegre, v. 1, n. 2, p. 12-16, 2001.

Cultura jurídica e práticas policiais: a tradição inquisitorial. In: KANT DE LIMA, R.; MISSE, M. (Orgs.). Ensaios de antropologia e de direito: acesso à Justiça e processos institucionais de administração de conflitos e produção da verdade jurídica em uma perspectiva comparada. 4. ed. Rio de Janeiro: Lumen Júris, 2011. p. 87-99.

KANT DE LIMA, R.; MISSE, M.; MIRANDA, A. P. Violência, criminalidade, segurança pública e justiça criminal no Brasil: uma bibliografia. Revista Brasileira de Informaçāo Bibliográfica em Ciências Sociais, São Paulo, n. 50, p. $45-123,2000$.

KAPPELER, V. E. The police and society: touchtone readings. 2. ed. Illinois: Waveland, 1999.

KLOCKARS, C. B.; STEPHEN D. M. Thinking about police: contemporary readings. 2. ed. New York: McGrawHill, 1991.

KUCINSKI, B. et al. (Orgs.). Bala perdida: a violência policial no Brasil e os desafios para sua superação. Saáo Paulo: Boitempo, 2015.

LEMGRUBER, J. O policial civil: conflitos e contradiçōes. Revista da OAB-RJ, Rio de Janeiro, n. 22, p. 207-236, 1985. . (Org.). Panorama das ouvidorias estaduais de segurança pública e defesa social. Rio de Janeiro: CESeC, 2013. (Nota técnica).

LEMGRUBER, J.; MUSUMESCI, L.; CANO, I. Quem vigia os vigias: um estudo sobre o controle externo da atividade policial no Brasil. Rio de Janeiro: Record, 2003.

LEMGRUBER, J. et al. Ministério Público: guardião da democracia brasileira. Rio de Janeiro: CESeC; UCAM, 2016. 
LIMA, R. Mapeamento das conexões teóricas e metodológicas da produção acadêmica brasileira em torno dos temas da violência e da segurança pública e as suas relaçōes com as políticas públicas da área adotadas nas duas últimas décadas (1990-2000). São Paulo: Fórum Brasileiro de Segurança Pública, 2008. (Relatório de pesquisa).

Panorama das ouvidorias estaduais de segurança pública e defesa social. Brasília, DF: Ministério da Justiça, 2013.

LIMA, R.; BUENO, S. (Orgs.). Polícia e democracia: 30 anos de estranhamentos e esperanças. São Paulo: Alameda, 2015.

LIMA, R.; BUENO, S.; SANTOS, T. Opiniāo dos policiais brasileiros sobre reformas e modernização da segurança pública. São Paulo: Fórum Brasileiro de Segurança Pública, 2014. (Relatório de pesquisa).

LIMA, R.; MUNIZ, J. O.; BUENO, S. Use com moderação. In: LIMA, R. (Org.). Narrativas em disputa: segurança pública, polícia e violência no Brasil. São Paulo: Alameda, 2016. p. 65-69.

LIMA, R.; RATTON, J. L.; AZEVEDO, R. G. (Orgs.). As ciências sociais e os pioneiros nos estudos sobre crime, violência e direitos humanos no Brasil. São Paulo: Anpocs; Urbania, 2011.

. (Orgs.). Crime, polícia e justiça no Brasil. São Paulo: Contexto, 2014.

LIMA, R. et al. Pesquisa de vitimização e percepção de risco entre os profissionais do sistema de segurança pública. São Paulo: Fórum Brasileiro de Segurança Pública, 2015. (Relatório de pesquisa).

LOPES, C. S. Como se vigia os vigilantes: o controle da Polícia Federal sobre a segurança privada. Revista de Sociologia e Política, Curitiba, v. 19, n. 40, p. 99-121, 2011.

. O setor da segurança privada da regiấo metropolitana de São Paulo: crescimento, dimensóes e características. Caderno CRH, Salvador, v. 26, n. 69, p. 599-617, 2013.

MACEDO, A. O. "Polícia, quando quer, faz!": análise da estrutura de governança do "Pacto pela Vida" de Pernambuco. 2012. 164 f. Dissertação (Mestrado em Ciências Sociais) - Universidade de Brasília, Brasília, DF, 2012.

MACHADO, B. A. Representações sociais sobre o controle externo da atividade policial: cultura organizacional e relaçôes institucionais. Revista Brasileira de Ciências Criminais, Brasília, DF, v. 19, n. 88, p. 56-67, 2011.

MACHADO, E. P.; NORONHA, C. V. A polícia dos pobres: violência policial em classes populares urbanas. Sociologias, Porto Alegre, v. 4, n. 7, p. 188-221, 2002a.

Padrōes de trabalho e tendências do uso da força policial no Brasil. In: LYRA, R. P. (Org.). Direitos humanos: os desafios do século XXI. Brasília, DF: Brasília Jurídica, 2002b. p. 225-240.

MACHADO, B. A.; PORTO, M. S. G. Homicídio na área metropolitana de Brasília: representaçóes sociais dos delegados de polícia, promotores de justiça e magistrados. Sociologias, Porto Alegre, v. 17, n. 40, p. 294-325, 2015. 
MACHADO DA SILVA, L. A. Refundar a polícia ou a sociedade? Observatório da Cidadania, Rio de Janeiro, v. 29, p. 18-21, 2009.

Polícia e violência urbana em uma cidade brasileira. Etnográfica, Lisboa, v. 15, n. 1, p. 67-82, 2011.

A experiência das UPPs: uma tomada de posiçăo. Dilemas, Rio de Janeiro, v. 8, n. 2, p. 7-24, 2015.

MAGUIRE, M.; MORGAN, R.; REINER, R. (Eds.). The Oxford handbook of criminology. 4. ed. Oxford: Oxford University Press, 2007.

MALAGUTI BATISTA, V. Estado de polícia. In: KUCINSKI, B. et al. (Orgs.). Bala perdida: a violência policial e os desafios para sua superação. São Paulo: Boitempo, 2015. p. 51-54.

MANNING, P. Os estudos sobre a polícia nos países anglo-americanos. Caderno CRH, Salvador, v. 18, n. 45, p. 431-446, 2005.

MARIANO, B. Ouvidoria de polícia: a constituição pública dos direitos humanos: a primeira experiência de ombudsman de polícia no Brasil. 2000. Dissertação (Mestrado em Ciências Sociais) - Pontifícia Universidade Católica de São Paulo, São Paulo, 2000.

MATTOS, G. Flagrantes de racismo: imagens da violência policial e as conexôes entre o ativismo no Brasil e nos Estados. Revista de Ciências Sociais, Fortaleza, v. 48, n. 2, p. 13-16, 2017.

MCLAUGHLIN, E.; MUNCIE, J. (Eds.). The Sage dictionary of criminology. 4. ed. Thousand Oaks: Sage, 2005.

MEDEIROS, A. M. Aspectos institucionais da unificação das polícias no Brasil. Dados, Rio de Janeiro, v. 8, n. 4, p. 19-27, 2004.

MELLO, M. M. P.; VALENÇA, M. A. Mulheres e controle policial no Recife do início do século XX. Caderno do Ceas, Salvador, n. 238, p. 659-677, 2016.

MENEZES, P. Entre o fogo cruzado e o campo minado: uma etnografia do processo de pacificaçâo de favelas cariocas. 2015. 65 f. Tese (Doutorado em Sociologia) - Universidade do Estado do Rio de Janeiro, Rio de Janeiro, 2015.

MESQUITA NETO, P. Policiamento comunitário e prevenção do crime: a visão dos coronéis da polícia militar. São Paulo em Perspectiva, São Paulo, v. 6, n. 1, p. 103-110, 2004.

MISSE, M. (Org.). Autos de resistência: uma análise dos homicídios cometidos por policiais na cidade do Rio de Janeiro (2011-2011). Rio de Janeiro: Núcleo de Estudos da Cidadania, Conflito e Violência Urbana, 2011a. (Relatório de pesquisa).

. O papel do inquérito policial no processo de incriminação no Brasil: algumas reflexôes a partir de uma pesquisa. Sociologia e Estado, Brasília, DF, v. 26, n. 1, p. 17-23, 2011 b.

MONJARDET, D. Profissionalismo e mediação da ação policial. Antropolitica, Niterói, n. 10-11, p. 7-29, 2001. 
O que faz a polícia: sociologia da força pública. São Paulo: Edusp, 2003.

MOREIRA, R. Entre o mito e a modernidade: a entrada de mulheres na Polícia Militar do Paraná. Guarapuava: Unicentro, 2016.

MORETZOHN, S. O sonho do capitão. In: CERQUEIRA, C. M. N. (Org.). O futuro de uma ilusāo: o sonho de uma nova polícia. Rio de Janeiro: Freitas Bastos, 2001.

MOURÃO, B. et al. Polícia, justiça e drogas: como anda nossa democracia? Rio de Janeiro: CESeC, 2016.

MUNIZ, J. Ser policial é, sobretudo, uma razão de ser: cultura e cotidiano da Polícia Militar do Estado do Rio de Janeiro. 1999. 289 f. Tese (Doutorado em Ciência Política) - Instituto Universitário de Pesquisas do Rio de Janeiro, Rio de Janeiro, 1999.

A crise de identidade das polícias militares brasileiras: dilemas e paradoxos da formação educacional. Security and Defense Studies Review, Washington, DC, v. 10, n. 1, p. 177-198, 2001.

Discricionariedade policial e a aplicação seletiva da lei na democracia. Ultima Ratio, São Paulo, v. 10, n. 2, p. $97-122,2008$.

. Despolitização da segurança pública e seus riscos. In: SOUZA, R.; GRACINO JÚNIOR, P. (Orgs.). Sociedade em perspectiva: cultura, conflito e identidade. Rio de Janeiro: Gramma, 2012a. p. 119-134.

O fim da inocência: um ensaio sobre os atributos do saber policial de rua. Marília: Oficina Universitária, 2012b. p. 13-41.

MUNIZ, J.; ALBERNAZ, E. R. Moralidades entrecruzadas nas UPPs: uma narrativa policial. Cadernos de Ciências Sociais, Porto, v. 29, p. 1-44, 2015.

MUNIZ, J.; MELLO, K. S. S. Nem tão perto, nem tão longe: o dilema da construçâo da autoridade policial nas UPPs: dossiê políticas públicas de segurança e justiça. Civitas, Porto Alegre, v. 15, n. 1, p. 44-65, 2015.

MUNIZ, J.; PAES MACHADO, E. Política para quem precisa de polícia: contribuiçôes aos estudos sobre policiamento. Caderno CRH, Salvador, v. 2, n. 60, p. 437-447, 2010.

MUNIZ, J.; PROENÇA JÚNIOR, D. Bases conceituais de métricas e padróes de medida de desempenho policial. In: CARUSO, H.; MUNIZ, J. O.; BLANCO, A. C. C. (Orgs.). Polícia, estado e sociedade: saberes e práticas latino-americanos. Rio de Janeiro: Publit, 2007a. p. 230-280.

. Da accountability seletiva à plena responsabilidade policial. In: CARUSO, H.; MUNIZ, J. O.; BLANCO, A. C. C. (Orgs.). Polícia, estado e sociedade: saberes e práticas latino-americanos. Rio de Janeiro: Publit, 2007b. p. 21-73.

Armamento é direitos humanos: nossos fins, os meios e seus modos. Sociedade e Estado, Brasília, DF, v. 28, n. 1, p. 42-37, 2013. 
. Jogando o jogo democrático da segurança pública: procedimentos, transparência e responsabilização policiais. In: PINHO, A. C. B.; DELUCHEY, J.-F.; GOMES, M. A. M. (Coords.). Tensöes contemporâneas da repressão criminal. Porto Alegre: Livraria do Advogado, 2014a. p. 147-158.

. Mandato policial. In: LIMA, R. S.; RATTON, J. L.; AZEVEDO, R. G. (Orgs.). Crime, polícia e justiça no Brasil. São Paulo: Contexto, 2014b. p. 491-502.

MUNIZ, J.; SILVA, W. F. Mandato policial na prática: tomando decisões nas ruas de João Pessoa. Caderno CRH, Salvador, v. 23, n. 60, p. 449-73, 2010.

MUSUMECI, L. Entre o grito e o tiro: polícia, democracia e armas "menos letais". Boletim Segurança e Cidadania, Rio de Janeiro, n. 16, p. 3-33, 2015.

MUSUMECI, L.; LEMGRUBER, J. Ouvidorias de polícia no Brasil, 15 anos depois. In: DURÃO, S.; DARCK, M. (Orgs.). Polícia, segurança e ordem pública: perspectivas portuguesas e brasileiras. Lisboa: Imprensa de Ciências Sociais, 2012. p. 219-248.

MUSUMECI, L. et al. (Coords.). Segurança pública e cidadania: a experiência de policiamento comunitário em Copacabana (1994-95). Rio de Janeiro: Iser, 1996. (Relatório final).

NASCIMENTO, A. A. A corrupção policial e seus aspectos morais no contexto do Rio de Janeiro. Revista Brasileira de Segurança Pública, São Paulo, v. 5, n. 9, p. 16-30, 2011.

Quando um homem da lei se torna um sem lei: os caminhos da corrupçấo policial. 2014. Tese (Doutorado em Sociologia) - Universidade Federal do Rio de Janeiro, Rio de Janeiro, 2014.

NEME, C. Projeto: o policiamento que a sociedade deseja: análise das discussōes em grupo com Oficiais da Polícia Militar do Estado de São Paulo. São Paulo: Núcleo de Estudos da Violência-USP, 2003. (Relatório).

NEVES, P. S. C. Qual polícia para qual sociedade? o policiamento comunitário em Sergipe. Caderno CRH, Salvador, v. 18, n. 45 , p. $447-459,2005$.

NEWBURN, T. (Ed.). Policing: key readings. Portland: Willan, 2005.

Handbook of policing. 2. ed. Portland: Willan, 2008.

OLIVEIRA, A. Os policiais podem ser controlados? Sociologias, Porto Alegre, v. 12, n. 23, p. 142-175, 2010.

OLIVEIRA, L. A polícia e as pequenas causas. Revista do Tribunal do Trabalho da 8 a Regiāo, Belém, v. 18, n. 35, p. 17-31, 1985a.

. Práticas judiciárias em comissariados de polícia do Recife. Revista da OAB-RJ, Rio de Janeiro, v. 8, n. 22, p. $160-171,1985$ b. 
. Sua Excelência, o Comissário. Cadernos do GAJOP, Olinda, v. 1, n. 1, p. 17-22, 1985c.

. Dos comissariados de polícia do Recife às UPPs do Rio de Janeiro: a polícia e a desjudicialização do direito processual nas "pequeníssimas" causas. In: PIMENTEL, A. F.; BARROSO, F. T.; GOUVEIA, L. G. (Orgs.). Processo, hermenêutica e efetividade dos direitos. Recife: Cefe, 2015. v. 2, p. 103-118.

OLIVEIRA, N.; RIBEIRO, L. M. S.; ZANETTI, J. C. A outra face da moeda: violência na Bahia. Salvador: CJP, 2000.

OLIVEIRA JÚNIOR, A. Cultura de polícia: cultura e atitudes ocupacionais entre policiais militares em Belo Horizonte. 2007. 212 f. Tese (Doutorado em Ciências Humanas) - Universidade Federal de Minas Gerais, Belo Horizonte, 2007.

OLIVEIRA NETO, E. A. Os cães ladram mas a caravana não para: estudo etnográfico sobre o policiamento com cáes no DF. 2016. 96 f. Dissertaçấo (Mestrado em Sociologia) - Universidade de Brasília, Brasília, DF, 2016.

PAES MACHADO, E.; NORONHA, C. V. A polícia dos pobres: violência urbana em classes populares urbanas. Sociologias, Porto Alegre, v. 4, n. 7, p. 188-221, 2002.

PAIXÃO, A. L. A organização policial em uma área metropolitana. Dados, Rio de Janeiro, v. 25, n. 1, p. 56-62, 1982.

O “problema da polícia”. In: INSTITUTO UNIVERSITÁRIO DE PESQUISAS DO RIO DE JANEIRO. Violência e participaçâa política no Rio de Janeiro. Rio de Janeiro: IUPERJ, 1995. p. 11.

PEREIRA, T. G. S. O tiro de misericórdia: uma análise dos fatores institucionais do suicídio na Polícia Militar do Estado do Rio de Janeiro. 2015. 157 f. Dissertação (Mestrado em Sociologia e Antropologia) - Universidade Federal do Rio de Janeiro, Rio de Janeiro, 2015.

PINC, T. Treinamento policial: um meio de difusão de políticas públicas que incidem na conduta individual do policial de rua. 2011. 246 f. Tese (Doutorado em Ciência Política) - Universidade de São Paulo, São Paulo, 2011.

PINTO, J. B. M. Pesquisa nacional sobre segurança pública e direitos humanos. In: LIMA, C.; BAPTISTA, G.; FIGUEIREDO, I. S. (Orgs.). Segurança pública e direitos humanos: temas transversais. Brasília, DF: Ministério da Justiça; Senasp, 2013. p. 83-252.

PINTO, N. M. et al. Cursos de pós-graduação em segurança pública e a construção da Renaesp como política pública: consideraçôes sobre seus efeitos a partir de diferentes olhares. In: LIMA, C.; BAPTISTA, G.; FIGUEIREDO, I. S. (Orgs.). Segurança pública e direitos humanos: temas transversais. Brasília, DF: Ministério da Justiça; Senasp, 2014. p. 226-260.

PONCIONI, P. Tornar-se policial: a construção da identidade profissional do policial no estado do Rio de Janeiro. 2004. Tese (Doutorado em Sociologia) - Universidade de São Paulo, São Paulo, 2004.

. O modelo policial profissional e a formação profissional do futuro policial nas academias de polícia do estado do Rio de Janeiro. Sociedade e Estado, Brasília, DF, v. 10, n. 3, p. 585-610, 2005. 
. Identidade profissional policial. In: LIMA, R. S.; RATTON, J. L.; AZEVEDO, R. G. (Orgs.) Crime, polícia e justiça no Brasil. São Paulo: Contexto, 2014. p. 503-510.

. O modelo de policiamento comunitário nos Programas de Educação Policial: uma breve revisão da literatura especializada sobre o assunto. Politeia, Lisboa, v. 1, n. 2, p. 127-140, 2016.

PORTO, M. S. G. Polícia e a violência: representaçóes sociais de elites policias do Distrito Federal. São Paulo em Perspectiva, Săo Paulo, v. 18, n. 1, p. 132-141, 2004.

PROENÇA JÚNIOR, D.; MUNIZ, J. Operaçōes especiais e segurança pública. Revista Brasileira de Segurança Pública, São Paulo, v. 11, n. 1, p. 182-195, 2017.

PROENÇA JÚNIOR, D.; MUNIZ, J.; PONCIONI, P. Da governança de polícia à governança policial: controlar para saber, saber para governar. Revista Brasileira de Segurança Pública, São Paulo, v. 3, n. 1, p. 14-37, 2009.

RAMALHO NETO, J. P. Farda e "cor": um estudo racial nas patentes da polícia militar da Bahia. Afro-Ásia, Salvador, v. 10 , n. 45 , p. $67-94,2012$.

RAMOS, S.; MUSUMESCI, L. Elemento suspeito: abordagem policial e discriminação na cidade do Rio de Janeiro. Rio de Janeiro: Record, 2005.

RAMOS, S.; PAIVA, A. A blogosfera policial no Brasil: do tiro ao Twitter. Brasília, DF: Unesco; Rio de Janeiro: CESeC, 2009.

RATTON, J. L.; TORRES, V. Consideraçôes sobre o inquérito policial: o que pensam policiais civis, defensores, promotores e juízes em Pernambuco. Cadernos Temáticos da Conseg, Brasília, DF, v. 1, p. 59-68, 2009.

REINER, R. A política da polícia. São Paulo: Edusp, 2001.

REIS, D. B. O racismo na determinação da suspeição policial: a construção social do suspeito. 2001. 200 f. Dissertação (Mestrado em Sociologia) - Universidade Federal da Bahia, Salvador, 2001.

A marca de Caim: as características que identificam o suspeito, segundo relatos de policiais militares. Caderno CRH, Salvador, v. 10, n. 36, p. 181-196, 2002.

REVISTA DO CNMP. Brasília, DF: CNMP, v. 1, n. 2, 2011.

RIBEIRO, L. M. L.; LEMGRUBER, J.; MUSUMECI, L. Panorama das ouvidorias estaduais de segurança pública e defesa social. Revista Brasileira de Segurança Pública, São Paulo, v. 1, n. 8, p. 138-163, 2014.

RIBEIRO, L. M. L.; MACHADO, I. S. Repressão, autonomia e responsividade: o direito que se exerce nas delegacias de polícia no Brasil. Sociedade e Estado, Brasília, DF, v. 29, n. 1, p. 153-180, 2014. 
RIBEIRO, L. M. L.; MONTANDON, A. M. A. Reformar a polícia ou reformar o seu discurso? uma análise da chegada da filosofia de policiamento comunitário a uma organizaçáo policial militar brasileira. Revista Brasileira de Segurança Pública, São Paulo, v. 9, n. 1, p. 62-81, 2015.

RIBEIRO, L. M. L.; OLIVEIRA, V. C. Quando o Estado é o perpetrador da violência: uma análise das vitimizaçôes ocasionadas pela Polícia Militar. Latitude, Maceió, v. 7, n. 2, p. 219-243, 2013.

Policiamento comunitário. In: LIMA, R. S.; RATTON, J. L.; AZEVEDO, R. G. (Orgs.). Crime, polícia e justiça no Brasil. São Paulo: Contexto, 2014. p. 527-538.

RIO DE JANEIRO. Assembleia Legislativa do Rio de Janeiro. Relatório final da Comissão Parlamentar de Inquérito destinada a investigar a ação de milícias no âmbito do estado do Rio de Janeiro. Rio de Janeiro: Alerj, 2009.

RODRIGUES, A. L. R. et al. O trabalho e seus sentidos: um estudo com peritos criminais da Polícia Federal. Revista de Administração Pública, Rio de Janeiro, v. 51, n. 6, p. 63-75, 2017.

ROMÃO, D. M. Hierarquia, aspectos da cultura organizacional e implicaçôes na qualidade de vida: um estudo das polícias militares brasileiras. Brasília, DF: Ministério da Justiça, 2016.

RUDNICKI, D. O ingresso de bacharéis em direito na polícia militar gaúcha. Sociologias, Porto Alegre, v. 10, n. 20, p. $108-137,2008$.

SÁ, L. Os filhos do Estado: autoimagem e disciplina na formação dos oficiais da Polícia Militar do Ceará. Rio de Janeiro: Relume Dumará, 2002.

SÁ, L.; SANTIAGO NETO, J. P. Entre tapas e chutes: um estudo antropológico do baculejo como exercício do poder policial no cotidiano da cidade. O público e o privado, Fortaleza, n. 18, p. 147-163, 2011.

SADEK, M. T.; ARANTES, R. B. Delegados de polícia: quem são e o que pensam. Cadernos Adenauer, Rio de Janeiro, v. 4, n. 3, p. 129-150, 2003.

SALES, L. M. M.; ALENCAR, E. C. O.; FEITOSA, G. R. Mediação de conflitos sociais, polícia comunitária e segurança pública. Sequência, Florianópolis, v. 30, n. 28, p. 25-36, 2009.

SANCHES, C.; SOUSA, E. N. Nova matriz curricular do curso de formação de oficiais: uma adequação ao perfil profissiográfico do Chefe de Polícia Ostensiva da PMGO. Revista Brasileira de Estudos em Segurança Pública, São Paulo, v. 1, n. 1, p. 10-54, 2008.

SANSONE, L. Fugindo para a força: cultura corporativista e "cor" na polícia militar do estado do Rio de Janeiro. Estudos Afro-Asiáticos, Rio de Janeiro, v. 24, n. 3, p. 512-532, 2002.

SANTANA, M. Sou policial, mas sou mulher: gênero e representaçôes sociais na polícia militar de São Paulo. 2015. 463 f. Tese (Doutorado em Sociologia) - Universidade de Campinas, Campinas, 2015. 
SILVA, C. C. Relacionamento entre os controles internos e externos da Polícia Militar do Distrito Federal: motivaçôes e perspectivas. 2008. 114 f. Dissertação (Mestrado em Sociologia) - Universidade de Brasília, Brasília, 2008.

SILVA, D. S.; RIBEIRO, L. M. L. Polícia comunitária em Belo Horizonte: a hora e a vez dos estabelecidos? Pensata, São Paulo, v. 4, p. 178-205, 2015.

SILVA, G. F.; BEATO FILHO, C. C. Confiança na polícia em Minas Gerais: o efeito da percepção de eficiência e do contato individual. Opiniāo Pública, Campinas, v. 19, n. 1, p. 118-153, 2013.

SILVA, G. G. A lógica da polícia militar do Distrito Federal na construção do suspeito. 2009. 187 f. Dissertação (Mestrado em Sociologia) - Universidade de Brasília, Brasília, DF, 2009.

Políticas de segurança pública: um olhar sobre a formação da agenda, das mudanças do padráo de policiamento e da manutençấo do policiamento comunitário no Distrito Federal. 2015. 198 f. Tese (Doutorado em Sociologia) - Universidade de Brasília, Brasília, DF, 2015.

SILVA, R. R. Entre a caserna e a rua: o dilema do pato: uma análise antropológica da instituição policial militar a partir da Academia de Polícia Militar Dom João VI. 2009. 279 f. Dissertaçáo (Mestrado em Antropologia) - Universidade Federal Fluminense, Niterói, 2009.

SINHORETTO, J. et al. A filtragem racial na seleção policial de suspeitos: segurança pública e relações raciais. In: LIMA, C.; BAPTISTA, G.; FIGUEIREDO, I. S. (Orgs.). Segurança pública e direitos humanos: temas transversais. Brasília, DF: Ministério da Justiça; Senasp, 2013. p. 121-158.

SKOLNICK, J. H.; BAYLEY, D. H. Nova polícia: inovaçôes na polícia de seis cidades norte-americanas. São Paulo: Edusp, 2002.

SOARES, B. M.; MOURA, T.; AFONSO, C. Auto de resistência: relatos de familiares vítimas de violência armada. Rio de Janeiro: 7Letras, 2009.

SOARES, B. M.; MUSUMECI, L. Mulheres policiais: presença feminina na Polícia Militar do Rio de Janeiro. Rio de Janeiro: Civilização Brasileira, 2005.

SOARES, B. M. et al. O que pensam os policiais das UPPs. Ciência Hoje, Rio de Janeiro, n. 294, p. 34-39, 2012.

SOARES, L. E. Meu casaco de general: 500 dias no front da segurança pública do Rio de Janeiro. Sáo Paulo: Companhia das Letras, 2000a.

. Segurança pública e direitos humanos: entrevista concedida a Sérgio Adorno. Novos Estudos Cebrap, São Paulo, n. 57, p. 141-154, 2000 b.

Novas políticas de segurança pública. Estudos Avançados, Săo Paulo, v. 1, n. 47, p. 75-96, 2003.

Legalidade libertária. Rio de Janeiro: Lumen Júris, 2006. 
A política nacional de segurança pública: histórico, dilemas e perspectivas. Estudos Avançados, São Paulo, v. 61, n. 21 , p. $77-97,2007$.

Arquitetura institucional da segurança pública no Brasil: três propostas de reforma constitucional. Luiz Eduardo Soares, Rio de Janeiro, 30 jul. 2012. Disponível em: <https://goo.gl/L1rJRb>. Acesso em: 12 abr. 2018.

Por que tem sido táo difícil mudar as polícias? In: KUCINSKI, B. et al. (Orgs.). Bala perdida: a violência policial no Brasil e os desafios para sua superação. Sáo Paulo: Boitempo, 2015. p. 27-31.

SOARES, L. E.; ATHAYDE, C.; MV BILL. Cabeça de porco. Rio de Janeiro: Objetiva, 2005.

SOARES, L. E.; BATISTA, A.; PIMENTEL, R. Elite da tropa. Rio de Janeiro: Objetiva, 2006.

SOARES, L. E.; LEMOS, C. E.; MIRANDA, R. Espirito Santo. Rio de Janeiro: Objetiva, 2008.

SOARES, L. E.; ROLIM, M.; RAMOS, S. O que pensam os profissionais de segurança pública no Brasil. Brasília, DF: Ministério da Justiça, 2009.

SOARES, L. E. et al. Elite da tropa II. Rio de Janeiro: Objetiva, 2010.

SOUZA, J. R. C. Controle externo da atividade policial. Brasília, DF: Consultoria Legislativa da Câmara dos Deputados, 2001.

SOZZO, M.; AZEVEDO, R. G. Segurança pública e reforma das polícias na América Latina. Civitas, Porto Alegre, v. 16, n. 4, p. 547-551, 2016.

STORANI, P. Vitória sobre a morte: a glória prometida: o rito de passagem na construção da identidade das operaçôes especiais do Bope. 2008. 170 f. Dissertação (Mestrado em Antropologia) - Universidade Federal Fluminense, Niterói, 2008.

Uso comedido da força letal: construindo um protocolo de engajamento. Cadernos Temáticos da Conseg, Brasília, DF, v. 1, n. 5, p. 47-58, 2009.

SUASSUNA, R. F. Confiança e reciprocidade entre policiais e cidadãos: a polícia democrática nas interaçóes. 2013. 233 f. Tese (Doutorado em Sociologia) - Universidade de Brasília, Brasília, DF, 2013.

TAVARES DOS SANTOS, J. V. Policía y seguridad ciudadana en Brasil. In: SIERRA, J.; BERNARDES ALVARADO, M. (Orgs.). Democracia, gobernanza y desarollo em el Mercosur. Montevidéu: Unesco; Clacso, 2004. p. 169-173.

Programas de Polícia Comunitária no Brasil: avaliação de propostas de políticas públicas de segurança. In: LIMA, C.; BAPTISTA, G.; FIGUEIREDO, I. S. (Orgs.). Segurança pública e direitos humanos: temas transversais. Brasília, DF: Ministério da Justiça; Senasp, 2013. p. 205-235.

TAVARES DOS SANTOS, J. V. et al. Mapeamento de modelos de ensino policial e de segurança pública no Brasil. São Paulo: Fórum Brasileiro de Segurança Pública, 2013. (Relatório de pesquisa). 
TURNER, V. W. O processo ritual: estrutura e antiestrutura. Petrópolis: Vozes, 2013.

UNIVERSIDADE FEDERAL DE MINAS GERAIS. Centro de Estudos de Criminalidade e Segurança Pública. Avaliação do policiamento comunitário da Polícia Militar de Minas Gerais em Belo Horizonte. Bele Horizonte: Crisp, 2009. (Relatório de pesquisa).

VARGAS, J. H. C. Apartheid brasileiro: raça e segregação residencial no Rio de Janeiro. Revista de Antropologia, São Paulo, v. 48, n. 1, p. 23-37, 2005.

VASCONCELOS, F. Esboço de uma sociologia política das ciências sociais contemporâneas (1968-2010): a formação do campo da segurança pública e o debate criminológico no Brasil. 2014. 519 f. Tese (Doutorado em Sociologia) Universidade de São Paulo, São Paulo, 2014.

VIEIRA, T. M. Nem junto, nem misturado: uma etnografia sobre paz e proximidade na UPP Nova Brasília no Complexo do Alemão. 2014. 115 f. Dissertação (Mestrado em Antropologia) - Universidade Federal Fluminense, Niterói, 2014.

ZACCONE, O. Indignos de vida: a forma jurídica da política de extermínio de inimigos da cidade do Rio de Janeiro. Rio de Janeiro: Revan, 2015.

ZACKSESKI, C. Diagnóstico sobre a situação das corregedorias das instituiçōes de segurança pública dos estados da regiāo Nordeste. Brasília, DF: PNUD; Senasp, 2016.

ZAFFARONI, E. Las "clases peligrosas": el fracaso de un discurso policial prepositivista. Sequência, Florianópolis, v. 26, n. 51, p. 15-19, 2005.

ZALUAR, A. Um debate disperso: violência e crime no Brasil da redemocratização. São Paulo em Perspectiva, São Paulo, v. 13 , n. 3, p. 3-17, 1999a.

Violência e crime. In: MICELI, S. (Org.). O que ler na ciência social brasileira (1970-1995). São Paulo: Sumaré; Anpocs, 1999b. v. 1, p. 13-107.

ZAVERUCHA, J. O papel da ouvidoria de polícia. Sociologias, Porto Alegre, v. 10, n. 2, p. 224-235, 2008.

ZILLI, L. F.; COUTO, V. A. Servir e proteger: determinantes da avaliação pública sobre a qualidade do trabalho das Polícias Militares no Brasil. Sociedade e Estado, Brasília, DF, v. 32, n. 3, p. 681-700, 2017.

\section{Resumo}

Os estudos policiais nas ciências sociais: um balanço sobre a produção brasileira a partir dos anos 2000

Este artigo discute a bibliografia brasileira das ciências sociais sobre os estudos policiais no período de 2000 a 2017. Inicialmente reconstrói o percurso sócio-histórico que levou a polícia a constituir-se em um problema sociológico. Em seguida classifica, descreve e analisa as temáticas exploradas pelos cientistas sociais brasileiros.

Palavras-chave: Polícia; Policiamentos, Estudos Policiais; Segurança Pública; Controle Social. 


\section{Abstract}

Police studies in social sciences: an overview about the Brazilian production as of the 2000s

This article discusses the Brazilian bibliography of social sciences on police studies from 2000 to 2017. First of all, it reconstructs the socio-historical course that made the police become a sociological problem. Then, it classifies, describes and analyzes the themes explored by Brazilian social scientists.

Keywords: Police; Policing, Police Studies; Public Security; Social Control.

\section{Résumé}

Les études de police dans les sciences sociales : un bilan de la production brésilienne à partir des années 2000

Cet article analyse la bibliographie brésilienne des sciences sociales sur les études policières entre 2000 et 2017. D'abord il reconstitue le processus socio-historique qui a conduit la police à être considérée comme un problème sociologique. Ensuite il classifie, décrive et analyse les thématiques étudiées par les chercheurs brésiliens en sciences sociales.

Mots-clés: Police; Actions Policières; Études Policières; Sécurité Publique; Contrôle Social. 